University of San Diego

Digital USD

Theses

Theses and Dissertations

Winter 1-1-2017

\title{
American Civil War Reenactments: Race and Masculinity in Modern Images and Memory
}

Austin C. English

University of San Diego

Follow this and additional works at: https://digital.sandiego.edu/theses

Part of the United States History Commons

\section{Digital USD Citation}

English, Austin C., "American Civil War Reenactments: Race and Masculinity in Modern Images and Memory" (2017). Theses. 19.

https://digital.sandiego.edu/theses/19

This Thesis: Open Access is brought to you for free and open access by the Theses and Dissertations at Digital USD. It has been accepted for inclusion in Theses by an authorized administrator of Digital USD. For more information, please contact digital@sandiego.edu. 
UNIVERSITY OF SAN DIEGO

\section{AMERICAN CIVIL WAR REENACTMENTS: \\ RACE AND MASCULINITY IN MODERN IMAGES AND MEMORY}

A Thesis submitted in partial satisfaction of the requirements for the degree of

Master of Arts in History

by
Austin Curtis English

Thesis Committee

Michael Gonzalez, Ph.D., Chair

David Miller, Ph.D. 
I'm dying now, so if you want my granddaddy's uniform it's upstairs in a closet.

Tony Horwitz

Confederates in the Attic 
The Thesis of Austin Curtis English is approved by:

Thesis Committee Chair

Thesis Committee Member

University of San Diego

San Diego

2017 


\section{Copyright 2017 Austin Curtis English}

Limitations: No part of this document may be reproduced in any form without the author's prior written consent for a period of three years after the date of submittal.

Austin Curtis English 
Dedicated to the passionate Professors of History at the University of San Diego and my inspirational mother, loving girlfriend, supportive grandparents, and the Nio Family. Thank you for always being full of endless love and support.

And for Dad and Papa with all of my love. Always a good day to Go Get 'Em! 
TABLE OF CONTENTS

LIST OF FIGURES/ILLUSTRATIONS............................................. vi

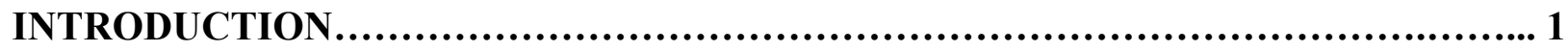

CHAPTER ONE: THE ORIGIN OF REENACTMENTS AND THE MYTH OF THE

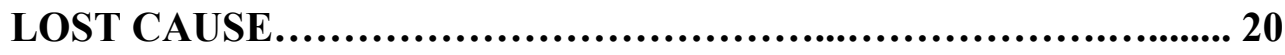

CHAPTER TWO: THE POLITICS OF REENACTMENTS................................37

CHAPTER THREE: THE CIVIL WAR AND THE VICTORY OF THE SOUTH.........55

CONCLUSION: THE FUTURE OF REENACTMENTS..............................................73

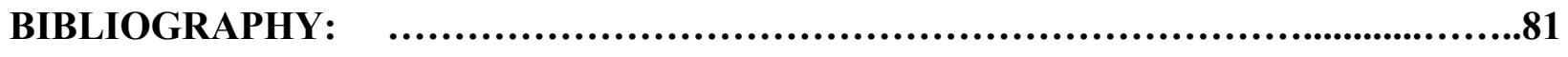




\section{LIST OF FIGURES / ILLUSTRATIONS}

Figure 1.1 - Decoration Day (1885)....................................................22

Figure 1.2 - Confederate Veterans (1890s)..............................................24

Figure 1.3 - Commemoration of Pickett's Charge (1963)..................................27

Figure 1.4 - Southern and Northern veterans shake hands (1913)..........................32

Figure 1.5 - Veterans shake hands at stone wall, Battle of Gettysburg reunion (1913)......34

Figure 1.6 - President Wilson at Fiftieth Anniversary of Gettysburg (1913)................35

Figure 2.1 - Union reenactors at Battle of Vista, San Diego (2011).........................41

Figure 2.2 - Confederate reenactors at Battle of Vista, San Diego (2011)..................43

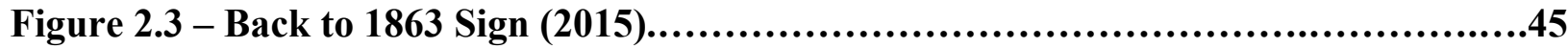

Figure 2.4 - Leaders and Generals of the Civil War (2015)..............................47

Figure 2.5 - Sgt. Petzolt at the top of Little Round Top in Gettysburg, PA (2013)...........49

Figure 2.6 - Confederate reenactors teaches young students..............................51

Figure 2.7 - Confederate Selfie and Dandy Confederates (2011)...........................52

Figure 3.1 - Camp at Battle of Vista Reenactment in San Diego, CA (2015).................59

Figure 3.2 - African American Union reenactor stands alone (2015).......................60

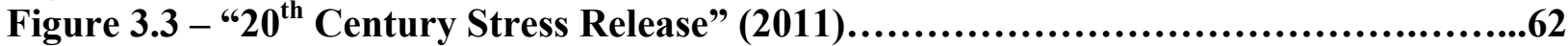

Figure 3.4 - Confederate Battle Flag Rally (2015)........................................69

Figure 3.5 - "Turn Your Back on Hate" ..................................................69

Figure 3.6 - Ku Klux Klan Cross Burning (2016).......................................70

Figure 4.1 - Azie Dungey, creator and star of Ask $A$ Slave..................................73

Figure 4.2 - Reenactor teaches and Confederate Battle Flag "Offends"

Figure 4.3 - Young Confederate at Battle Flag Rally and Union reenactor in camp..........77 


\section{INTRODUCTION}

To accept one's past—one's history — is not the same thing as drowning in it; it is learning how to use it. An invented past can never be used; it cracks and crumbles under the pressures of life like clay in a season of drought. ${ }^{1}$

\section{- James Baldwin}

The celebration of past wars and warriors is not a uniquely American notion. For centuries nations and individuals have celebrated and revered those who went to war. Similarly, modern Civil War reenactments represent one ritual where Americans honor the War and its participants. But is there something distinctive about the way Americans commemorate and remember the Civil War? Do reenactments hide, forget, or obscure certain elements of the War as much as they commemorate? From the bloody fields of Gettysburg to distant dirt lots in Southern California, contemporary twenty-first century "soldiers" reenact the Civil War. Reenactments attract those who seek "camaraderie" and wish to experience a communal, recreational, or historical connection to the Civil War. ${ }^{2}$ Gettysburg's $150^{\text {th }}$ anniversary and reenactment in 2013 attracted 111,000 visitors from July 1-4. ${ }^{3}$ Although reenactments primarily take place at locations with historical value, a mutual appreciation for the War inspires Americans to recreate battles as far west as California. ${ }^{4}$ Many reenactors want to create a historical connection with those who lived through a devastating time in American history. ${ }^{5}$ The writer James Baldwin believed that we must learn "how to use" history, but it must be used

\footnotetext{
${ }^{1}$ David Blight, American Oracle: The Civil War in the Civil Rights Era (London: Harvard University Press, 2011), 183, and James Baldwin, The Fire Next Time (1963).

${ }^{2}$ American Civil War Association, About, http://www.acwa.org/about.

${ }^{3}$ Kathryn Jorgensen, "Gettysburg $150^{\text {th }}$ Brings Thousands to Programs, Battlefield, Reenactments," CivilWarNews.com (Historical Publications Inc., August 2013).

${ }^{4}$ Gold Coast Festivals, Vista Civil War Reenactment, 2014. Southern California Reenactment Association.

${ }^{5}$ American Civil War Association, About (Drupal, 2012).
} 
responsibly because "an invented past can never be used." Baldwin testifies to the responsibility of communicating an exact history and relaying those truths and memories to society. Additionally, Baldwin can also speak to Civil War reenactments in modern America. Reenactments "use" and reinvent historical memories all the time, so does this example confirm Baldwin's observations? When people misuse, or refuse to heed lessons from the past, that history "cracks and crumbles" under the weight of its own internal contradictions. ${ }^{7}$

Correspondingly, reenactments make the past unusable when reenactors use history and distort the War's impact on the institution of slavery. This thesis will consider the sanitization of reenactments and how they distort a modern understanding of the War. Additionally, modern discrepancies over the meanings of the War are indicative of modern American anxieties. Scholars like David Blight acknowledge how Americans remain unsettled about remembering the War. He says, "And if the Civil War and Emancipation stimulated...meditations when those events turned 100 in American memory, how will our culture remember and explain them at $150 ?^{\prime 8}$ Only with time will an American public decide where reenactments fit into society whether they are historical or recreational.

Although involvement has declined in recent years, an estimated 30,000 individuals participate in American Civil War reenactments across the United States. ${ }^{9}$ American Civil War reenactments replicate camp life, military strategy, and battle experiences in order to "reproduce" a particular event, ideally, at the site of the original battle. One example of an organization that coordinates these efforts is the American Civil War Association, founded in 1994 to organize

\footnotetext{
${ }^{6}$ Blight, American Oracle: The Civil War in the Civil Rights Era (London: Harvard University Press, 2011), 183, and James Baldwin, The Fire Next Time (1963).

${ }^{7}$ Ibid.

${ }^{8}$ Blight, American Oracle, 24.

${ }^{9}$ Gigi Douban, Fewer People Participate in Civil War Reenactments (NPR Radio; Conversation Between Gigi Douban and Mr. John Nettles, July 4, 2011). Conversation seen at: http://www.npr.org/2011/07/04/137609367/fewer-people-participate-in-civil-war-reenactments.
} 
reenactors in California. The Association restricts the events of the War to a four-year period of battles and downplays the importance of slavery, all the while highlighting the importance of using the right equipment. The American Civil War Association says:

For four years the country ripped itself apart in a great war that was to decide the many questions left unanswered since the days of its birth. When it finally ended, the United States was again one nation but no less than 620,000 men, two percent of the population, had perished for what they believed. Our members attempt to educate the public and each other on this most pivotal era through battle reenactments, recreations of authentic camps and school programs. With the uniforms, clothing and equipment of the period one can get some small sense of how the men, women and children lived through the hardship that was the Civil War and also enjoy the very unique camaraderie and friendships that the hobby of reenacting offers. ${ }^{10}$

If the War was so significant and represented a time when soldiers "perished for what they believed" then it is not unreasonable to ask, what were those beliefs? ${ }^{11}$ Are they really reliving battles to commemorate the proper use of uniforms and weapons? James McPherson's What They Fought For, 1861-1865 lists numerous motivations during the War and notes: "Absurdity or not, most Confederate soldiers believed that they were fighting for liberty and slavery, one and inseparable."12 Both Union and Confederate soldiers, alike, thought "they were upholding the legacy of the American Revolution" and the right to own slaves equated to states' rights. ${ }^{13}$ Historically, states' rights referred to the right to own slaves and defend the institution of slavery. As for the American Civil War Association, it fails to underscore any of these pertinent "beliefs" that McPherson describes, regardless of the admission that, "questions," are left "unanswered.",14 Are these questions really left unanswered and, even if unsettled, do those beliefs not deserve equal discussion? What role do battles and "friendships" fulfill in honoring the beliefs of those

\footnotetext{
${ }^{10}$ American Civil War Association, About, http://www.acwa.org/about.

11 Ibid.

12 James McPherson, What They Fought For, 1861-1865 (Louisiana State University Press: First Anchor Books, 1995), 51.

13 Ibid., 27.

${ }^{14}$ American Civil War Association, About, http://www.acwa.org/about.
} 
"620,000" dead men that suffered through one of the bloodiest times in American history? ${ }^{15}$ Reenactors at the Gettysburg Anniversary Committee's sesquicentennial claimed that recreating a "pivotal battle that took place in July 1863 is a tribute to the soldiers who gave their all more than 150 years ago." ${ }^{\prime 6}$ Is shooting and playing dead the best way to pay tribute? Regardless of the individual choice to participate, paying "tribute" in the form of reenactments only further suppresses important discussions surrounding race and perpetuates nineteenth century notions of white masculinity in a twenty-first century America. This white masculinity, marked by the dominance of white men in American society, will be defined and addressed later in detail. ${ }^{17}$ As indicated by the American Civil War Association, reenactments are precise about the weaponry and style of the uniform. The reenactors only care about how they look or how they fight. Civil War reenactments, characterized by the correct equipment, uniforms, and precise accessories, obscure essential discussions of race during and after the War.

Technically, a grown man dressed in nineteenth-century period attire offers insight and a potential experience about military life during the American Civil War. However, this performance harms the way Americans see themselves and society. This is because reenactments support a limited perspective and encourage the diminishment of the racial implications. An emphasis on physical appearance romanticizes the individual experiences and hardships of soldiers. Yes - the correct weapons, clothes, camp supplies, and battle tactics are historically accurate; but, does this make these elements more important than other details? What about the 4 million newly "freed" slaves, their stories, and their disenfranchisement for the

\footnotetext{
${ }^{15}$ Ibid.

${ }^{16}$ Gettysburg Anniversary Committee, About GAC (Gettysburg Anniversary Civil War Reenactment, 2014), http://www.gettysburgreenactment.com/about-gac/.

${ }^{17}$ Refer to Footnote 44 for details from Gail Bederman.
} 
proceeding one hundred years? As a result, the perspectives of white men supersede the AfricanAmerican view of the War and substantive issues.

Modern American Civil War reenactments fail to address the complex, yet essential, issues of race. Reenactors often venerate notions of "Living History" where the individual experience of soldiers and the accuracy of military appearance are prioritized over all other elements of the War. ${ }^{18}$ This emphasis on accurate clothing, weapons, and battlefield tactics leaves reenactors and viewers with a narrow understanding of the American Civil War. The War is defined by superficial elements rather than by relevant social, cultural, and racial consequences. By 1864, the Civil War was not just about states' rights, but about millions of slaves and their potential freedom. President Abraham Lincoln's Gettysburg Address in 1863 referred to "a new birth of freedom" for enslaved blacks in the United States and the need for change. Lincoln's words acknowledged spilt blood, but not for the sake of the battles fought or the generals who waged it. President Lincoln understood that this bloodshed could renew the nation and promise equality to blacks. This renewal paved a way for the $13^{\text {th }}, 14^{\text {th }}$, and $15^{\text {th }}$ Amendments to the United States Constitution and empowered future generations of black Americans. The abolition of slavery, recognition of citizenship, and the right to vote represented milestones for former slaves in America and these social changes are necessary for the understanding of the Civil War, what it was about, and what it meant for future generations. Slavery - its expansion or its abolition - became the whole point of the War and modern reenactments avoid these fundamental questions of race. Consequently, modern reenactments create and preserve an incomplete historical memory devoid of slavery and racial implications.

\footnotetext{
${ }^{18}$ Civilwartraveler.com. Displays a number of references to participate in or view Living History.
} 
But what do reenactors believe? Many prominent academics have grappled with the understanding of the Civil War and why many white Americans do not want to consider race.

Before discussing how reenactments reflect modern attitudes and racial anxieties, it is important to discuss how other scholars perceive reenactments. Author and journalist Tony Horwitz discusses the perpetuation of the "noble" Lost Cause myth in the American South. He says "the issues at stake in the Civil War-race in particular—remained raw and unresolved."19 Horwitz concludes, after his two-year journey through fifteen States, that Americans remain unsettled with notions of race and, as a consequence, misconceptions about the War persist. Horwitz is a keen observer, but he did not address how modern reenactments shape popular memory about the Civil War.

Rory Turner, meanwhile, analyzes the culture of reenactments and acknowledges that, although he sees "some African-American spectators at reenactments, and there are a handful of black Union reenactors, the hobby is largely a white affair. ${ }^{20}$ His analysis recognizes both the "marginal roles" of women and, conversely, the prevalence of white men, but Turner's analysis is incomplete. He downplays these marginal experiences and the absence of black and female narratives as part of "a complex and intriguing game, an opportunity to go camping and get drunk with friends, an alternative to a dreary existence... or a fascinating window on a world they know from books and photographs but have never participated in as an experienced reality."21 Turner fails to understand that reenactments distort history. He identifies the imperfect narrative presented by reenactments, but falls short of seeing how those factors detract from and

\footnotetext{
${ }^{19}$ Tony Horwitz, Confederates in the Attic: Dispatches from the Unfinished Civil War (New York: Vintage Books, 1998), 386.

${ }^{20}$ Rory Turner, "Bloodless Battles: The Civil War Reenacted,” TDR, Vol. 34, No. 4: MIT Press (1990): 129.

${ }^{21}$ Ibid., 130-131.
} 
manipulate the historical record. His conclusions imply that reenactments have no relevant, modern applications.

Meanwhile, Mark Auslander says reenactments emphasize the traumatic experiences of the Civil War. By striving for authenticity, reenactors express their reverence for the War. He acknowledges both the inherent racial and gender-centered shortcomings of reenactments and identifies the physical reenactor as "a prosthetic symbolic male white body, embedded in an archaic racialized gender system: the clothing and the tools normally intensify male whiteness." ${ }^{22}$ While relevant, this is the extent of his observation and he fails to identify the shortcomings of an exclusively white, masculine portrayal of the Civil War.

Christopher Bates, who researches twenty-first century reenactments, attacks the research of scholars, like Horwitz, and defends reenactors, suggesting that they suffer "by association," with, "white supremacist interpretation of the war, new-Nazis for Klansman, despite being a broad community whose thinking is quite diverse."23 Bates incorporates thorough research about reenactments, but he avoids addressing the social and racial shortcomings of the War. Bates insists that the, "current generation of reenactors has little power to change the meaning that outsiders ascribe to their activities," and absolves reenactments of any responsibility in presenting an accurate portrayal of the racial or social issues of the War. ${ }^{24}$ He vindicates reenactors and defends the American South from a history of "stereotypes" marked by negative imagery that positions popular media against reenactors. ${ }^{25}$ Although Bates bases his argument on statistics, he defines the racial shortcomings of reenactments as the product of unfair,

\footnotetext{
${ }^{22}$ Mark Auslander, “Touching the Past: Materializing Time in Traumatic "Living History” Reenactments," Signs and Society, Vol. 1, No.1 (2013): 169.

${ }^{23}$ Christopher Bates, "What They Fight For: The Men and Women of Civil War Reenactment" (PhD diss., University of California Los Angeles, 2016), 106 and 17.

${ }^{24}$ Ibid., 106.

${ }^{25}$ Ibid., 119
} 
Southern stereotypes that paint, "groups as Civil War reenactors with too broad a brush."26 Bates dismisses critics of reenactments and suggests they promote negative stereotypes. But in doing so, he fails to properly identify the roots and consequences of racially biased Southern attitudes that neglect issues of race in modern reenactments.

David Blight highlights the "Reconciliation Myth" in which Northern and Southern veterans ignored the racial implications of the War by adopting a policy of reunion by the $1870 \mathrm{~s}$ and into the following decades. Similar to the Lost Cause myth, "what" they fought for or "why" no longer matters because by the turn of the nineteenth century, "North and South would yet find a way to sentimentalize and reconcile even this element of the war's aftermath." ${ }^{27}$ What happens to former slaves no longer matters. American culture and society cope with racial matters by suppressing them, Blight argues, and these sentiments are reflected in national commemorations like Decoration Day. This celebration grows out of the commemoration of the War and the American need to make sense out of the 620,000 who died from both sides. ${ }^{28}$ Americans now know Decoration Day as Memorial Day, but the commemoration of fallen soldiers still lies at the heart of the celebrations. During the nineteenth century, Civil War memories dwelled on sacrifice and not black emancipation and it was through these celebratory reunions that veterans began to reenact past battles. ${ }^{29}$ It is in this context and setting where "Union and Confederate veterans began to participate in Memorial Day exercises together in both North and South, ${ }^{, 30}$ and the "issue of race" is hidden "behind a rhetoric of reunion." 31 Blight's analysis stresses the evolution of American memory and the ways in which Americans remember the Civil War. His

\footnotetext{
${ }^{26}$ Ibid., 145.

${ }^{27}$ David Blight, Race and Reunion: The Civil War in American Memory (London: Harvard University Press, 2001), 122.

${ }^{28}$ Ibid., 64-65.

${ }^{29}$ Ibid., 182.

${ }^{30}$ Ibid., 86.

${ }^{31}$ Ibid., 91.
} 
argument establishes a key item that as Americans make sense of the War, myths are glorified as truths are suppressed. Therefore, if reenactments grow out of celebrations like Decoration Day, then reenactments are directly grounded in a history of limited memory, myth, and misconception. Blight's insights help explain reenactments in the twenty-first century. While all of these Civil War researchers and scholars share a common passion and curiosity for reenactments, none, however, argue that modern Civil War reenactments suppress African-American narratives. Reenactments are an important cultural phenomenon in a twentyfirst century America struggling with race and its place in society. The modern reenactment forms an incomplete, historical memory that speaks of unsettled anxieties over race and masculinity in twenty-first century America. Furthermore, modern reenactments provide a window into the white male's state of mind, revealing these unsettled anxieties. When asked at Little Round Top in Gettysburg, Pennsylvania, "What is significant about the Reconstruction period following the War," living historian "Sgt. Petzolt" stated simply: "Trying to keep the country together."32 Sgt. Petzolt says nothing about African-Americans, the failures of Reconstruction, or other pertinent issues unrelated to the narratives of white, male soldiers. The reenactments of the twenty-first century reflect narrow representations and diminished understandings of race, while celebrating whiteness in America.

A limited historical memory that capitalizes on military details over racial concerns has consequences in modern times. First, reenactors and their organizations perpetuate myths and misleading historical memories that extend back to the nineteenth century. ${ }^{33}$ Second, essential issues of slavery, race, and black disenfranchisement are excluded from modern discussions and

\footnotetext{
${ }^{32}$ Interview with "Living Historian” Sgt. Petzolt: Little Round Top, Gettysburg, PA, July 25, 2013.

${ }^{33}$ Refer to notes and discussion on Jennifer Eberhardt's Presentation on pages 14-15. Her examinations and conclusions indicate that modern Americans perceive race implicitly and maintain social and racial anxieties pertaining to black crime associations. These anxieties and negative associations suggest modern Americans remain unsettled regarding many cultural and racial issues.
} 
this only further re-emphasizes the roles of white men in American history. This focus on a nineteenth-century masculine history through downplaying racial issues is indicative of, and reflects, twenty-first century male anxiety and unsettled concerns regarding race after the Civil War. A historical memory that misleads and perpetuates itself gives voice to Baldwin's concerns and raises the question: how do reenactments perpetuate narrow memories and what processes contribute to the manufacturing of faulty memories? Furthermore, what are the social consequences of this struggle between useable memories and historical truths? Finally, does this struggle reflect modern attitudes about race and masculinity? The subject of white anxiety regarding race and masculinity in America requires further discussion in order to facilitate discussions concerning modern reenactments.

Historians agree that a white narrative dominates America's past. But what factors threaten or undermine white male dominance and instigate fears and social anxieties? Moreover, is there a connection between these anxieties and why white men reenact? According to Gail Bederman, the term "white" refers to Anglo-Protestant men and these "white men were the highest evolved of animals... served to bolster not only male superiority over women, but also white superiority over other race, and, in particular, the African-American." ${ }^{, 34}$ Bederman focuses on events from a century ago, but her definitions still apply to modern times. Racial anxieties often concern white male fears about his inadequacy and his suspicion about African-Americans, and this anxiety has persisted since the latter part of the nineteenth century. Fears concerning economics, gender roles, and race encourage anxieties in American white men. The acts and deeds of these men controlled the historical record in order to preserve white supremacy in America. Such exclusivity served to strengthen the white narrative and to degrade African-

\footnotetext{
34 Gail Bederman, Manliness and Civilization: A Cultural History of Gender and Race in the United States, 18801917 (Chicago and London: The University of Chicago Press, 1995), 307.
} 
Americans. Nineteenth-century white men, anxious and fearful about losing their place in society, resolve their concerns by suppressing African Americans throughout American history. Similarly, when twenty-first century reenactors don uniforms, their reenactments embody the same anxieties.

Modern reenactments, implicitly or explicitly, let white men reinvent themselves and shore up their confidence in a diverse, twenty-first century America. The historian Nancy MacLean suggests that after the Civil War a nineteenth-century, middle-class man felt "his standing (in society) was unstable, and he knew it." ${ }^{, 35}$ MacLean highlights a white male dominance unsettled by social threats: "In concrete terms, it meant losing control not only over their own labor, but also over African Americans, male and female, and the women and children in their own households." ${ }^{, 36}$ Correspondingly, modern America is a product of this atmosphere that "we still inhabit... and nineteenth-century manhood," continues to "impinge on us daily.",37 The fears that MacLean describe persist into the present. Civil war reenactments are another means by which white men commemorate and preserve their place in society. More precisely, modern reenactments use role-playing to compensate for these white male anxieties and ease this discontent.

The scholar James Gibson highlights the dominance of white men in the twentieth century and his analysis reveals the anxieties of a white male demographic that typically reenacts. He describes the individuals who make up this narrative and how American white men project their dominance: "Bankers, professors, factory workers, and postal clerks could all transcend their regular stations in life and prepare for heroic battle against the enemies of

\footnotetext{
${ }^{35}$ Nancy MacLean, Behind the Mask of Chivalry, the Making of the Second Ku Klux Klan (New York: Oxford University Press, 1994), 59.

${ }^{36}$ Ibid., 74.

${ }^{37}$ E. Anthony Rotundo, American Manhood: Transformation in Masculinity from the Revolution to the Modern Era (New York: Basic Books, Inc., 1993), 8-9.
} 
society." 38 Gibson would agree that some modern Americans fear a loss of their white dominance. For example, Cliven Bundy - a Nevadan cattle rancher - provoked national controversy in 2014 when he argued the government was infringing on his property rights. Bundy started an armed standoff over ranch property in opposition to U.S. Government claims over the land. A white, land-owning, and conservative farmer, Bundy implied AfricanAmericans had been better off as slaves while he argued on television that the government overstretched federal powers. The coverage of the story and Bundy's racial comments gained national attention. His comments and refusal of government power was met by the support of many white Americans. ${ }^{39}$ Social anxieties unite white males against segments of American society and this thesis will explore Southern sensibility.

Reenactments provide an opportunity to preserve and promote this white narrative. Moreover, the dominance of this white, male-centered narrative was historically reinforced in society through the public humiliation or mutilation of African-Americans. The scholar Orlando Patterson highlights the volatile, violent events following the Civil War, such as public lynchings where white children watched black men hanged and burned amidst crowds yelling, "“No, no...let them learn a lesson.",40 These public events represent the social and racial atmosphere that the War produced, particularly in the American South. White social dominance was inherently linked to the degradation and disenfranchisement of African-Americans. Patterson highlights the "old pro-slavery" argument whereas "Afro-Americans were unchangeable savages" that were blessed to have masters, otherwise they were bound for a life of barbarism

\footnotetext{
${ }^{38}$ James Gibson, Warriors Dreams, Violence and Manhood in Post-Vietnam America (Canada: First Hill and Wang, 1994), 9.

${ }^{39}$ Catherine Thompson, "Cliven Bundy Wonders if Blacks are 'Better Off as Slaves' than on Gov't Assistance," TalkingPointsMemo, April 24, 2014, http://talkingpointsmemo.com/livewire/bundy-explains-slavery-remarks. ${ }^{40}$ Orlando Patterson, "Rituals of Blood: Sacrificial Murders in the Postbellum South," Journal of Blacks in Higher Education, No. 23 (1999): 124.
} 
and "would undermine everything worthwhile and 'civilized' in southern life."41 His examination is founded in "historical and survey data," and "provides a glimpse of the tremendous cost to African-Americans of oppressive race relations, as well as the current state of race relations and some of the obstacles impeding further relief of the strained relations between African and European Americans." ${ }^{, 2}$ Reenactments help white males - or some of them at least - preserve their masculinity by venerating nineteenth-century values.

Furthermore, E. Anthony Rotundo's evaluations of nineteenth-century black men and middle-class white men are applicable to twenty-first century reenactments. Rotundo examines the exclusion of blacks in American society by "the most influential group of Americans in the nineteenth century: white, middle-class, Yankee Northerners." ${ }^{43}$ The depictions communicated through reenactments reinforce white narratives and suppresses the racial significance of the War well into the twenty-first century. Rotundo's evaluation emphasizes African-Africans, their significance, and complex history - all critical parts of America's past: "This small number of black men came to their middle-class status by a route so painfully different from that of whites that they deserve separate treatment and should not be thrown into the mix of white, middle-class Yankees who populate this book."44 This analysis is applicable to Civil War reenactments because these events fail to portray the Civil War as a complex, paradigm-shifting event. Building on both Patterson's and Rotundo's ideas, this thesis focuses on the undeniable relevance of nineteenth-century race issues and, equally, the overbearing presence of a white narrative in twenty-first century Civil War reenactments. Both white and black Americans have a complex history that remains unresolved in many ways and reenactments represent the

\footnotetext{
${ }^{41}$ Ibid., 123.

${ }^{42}$ Marino Bruce, "Race and Gender Relations in Rituals of Blood," Contemporary Sociology 29 (2000): 339. A review of Rituals of Blood: Consequences of Slavery in Two American Centuries by Orlando Patterson.

${ }^{43}$ Rotundo, American Manhood, ix.

${ }^{44}$ Ibid., 297.
} 
diminishment of these racial issues. Modern reenactments negate an inclusive, African

American narrative of the War and emphasize a white identity defined by racial and social dominance in American history.

Bederman classifies "manliness" and "masculinity" as essential elements used to sustain racial and social dominance in America. 45 "Manliness" represented Victorian conceptions of manhood such as strength, will, and sexual restraint, whereas the term "masculinity" only "emerged later to define the new ideal males (aggressive, physical, sexual)." ${ }^{46}$ Both terms are indicative of the evolving nature of manhood in America, which is always aiming to maintain dominance in society - but for the purposes of this examination, the term "masculinity" is more appropriate because it derives from earlier Victorian principles and features modern notions relevant to discussing twenty-first century anxieties. ${ }^{47}$ These masculine notions endure into modern times. This analysis will explore the presence of these Victorian principles in modern reenactments and how they perpetuate nineteenth-century conceptions of masculinity. Rotundo traces the transformation of masculinity in America and determines that "our beliefs about manhood have played a powerful role in determining the kind of life and kind of society we have." ${ }^{48}$ This framework suggests that the roles played by men at Civil War reenactments reflect their real world desires. Rotundo concludes that white men adapt to maintain dominance "in the

\footnotetext{
${ }^{45}$ Arnaldo Testi, review of Manliness and Civilization, by Gail Bederman. Journal of American History, Vol. 82, No. 4 (1996): 1590.

Gail Bederman, Manliness and Civilization: A Cultural History of Gender and Race in the United States, 1880-1917 (Chicago and London: The University of Chicago Press, 1995) 307.

${ }^{46}$ Ibid.

${ }^{47}$ Gail Bederman refers to "manliness" (aggressive, physical, sexual) as notions that develop later from Victorian values. The term "masculinity" will be used to refer to Bederman's definition of "manliness" with the condition that the term "masculinity" also incorporates Bederman's original Victorian description. This will allow for an analysis regarding nineteenth-century manhood and discussions over the extent to which twenty-first century reenactments reflect Victorian notions.

${ }^{48}$ Rotundo, American Manhood, 6.
} 
case of leisure, play, and consumption." ${ }^{49}$ The practices of white men are historically characterized by a desire to display masculinity, even if that means adapting and redefining social norms.

Rotundo's evaluation is applicable to Civil War reenactments and is another form of "leisure" by which white men promote masculinity. The American Civil War, when portrayed as a reenactment, does not refer to the plight of emancipated African American slaves or address the backwardness of white masculinity in the South. Hence, Civil War reenactments celebrate a white masculine America, marked by a history of male dominance in all aspects of society. Men adapt to maintain this dominance and, as Bederman says, masculinity becomes "a 'continual, dynamic process' that is constantly being remade. ${ }^{, 50}$ Thus, America's history is only for white men. Reenactments represent historical distortion and are a vessel by which white men celebrate their place in society. By emphasizing the battles and experiences of soldiers, reenactments relay imprecise perceptions that preserve male dominance. With all its complexities, the American Civil War requires discussions of motive, race, and gender. The continued pervasiveness of these faulty racial and masculine ideas in Civil War reenactments suggests that America has unresolved issues regarding race and the War.

But how do modern white Americans see blacks, and how would discussions pertaining to nineteenth-century issues of race and manhood enhance this perspective? Social Psychologist Dr. Jennifer Eberhardt spearheaded research concerning white fears about black criminality in modern American society. Her innovative work won a MacArthur Grant - $\$ 500,000$ for additional research on race and society. ${ }^{51}$ Her conclusions suggest overwhelmingly that many

\footnotetext{
${ }^{49}$ Ibid., 283.

${ }^{50}$ Bederman, Manliness and Civilization, 307.

${ }^{51}$ Richard Banks, Jennifer Eberhardt, and Lee Ross, "Discrimination and Implicit Bias in a Racially Unequal Society," California Law Review, Vol. 94, No. 4, July 2006, 1170.
} 
white Americans are indirectly conditioned to have anxieties, concerns, or fears deriving from black members of society. Dr. Eberhardt developed a series of scientific studies addressing whether there is a presence of racial bias amongst white Americans and measured the extent of these modern biases. Her research aims to "find evidence that race continues to influence individuals' decision-making and behavior." She uses "the Implicit Association Test (IAT), which aims to measure implicit bias that operates beyond individuals' conscious awareness, and may exist even among individuals who genuinely believe themselves to be unbiased." ${ }^{, 52}$ Dr. Eberhardt emphasizes that the test-subjects in the studies are predominantly white men. She suggests that social representations of race can affect neuro-processing and influence racial assumptions. Her scientific findings indicate the presence of bias amongst white Americans who often respond to black imagery with negative emotions. Furthermore, Eberhardt argues that most white Americans believe that racism is no longer a problem, think that everyone is treated fairly, and that no one experiences negative emotions when encountered with race. ${ }^{53}$ Although Eberhardt's research is noteworthy, it is not the first time sociologists, scientists, and historians have analyzed racial tensions in modern America. The racial atmosphere that Eberhardt describes is further supported by the General Social Survey (1983) and Public Opinion Poll Survey (2004): only 17 percent of white Americans report social issues as racial concerns, only seven percent think race is a social worry, and only six percent of Americans report contemplating racial issues. ${ }^{54}$ Eberhardt's conclusions concern all of these social misconceptions and reinforce other findings that indicate African-Americans are still subject to white anxieties.

\footnotetext{
52 Ibid.

${ }^{53}$ Jennifer Eberhardt, "How Racial Residue: how Race Alters Perception of People, Places, and Things (Lecture at Cornell University, College of Human Ecology, Human Development Outreach and Extension), February 18, 2011. URL: http://www.cornell.edu/video/how-race-alters-perception-of-people-places-and-things ${ }^{54}$ Ibid., General Social Survey (1983) and Public Opinion Poll Survey (2004) as referenced by Jennifer Eberhardt.
} 
American Civil War reenactments are another instrument by which white Americans reflect and reinforce social and racial anxieties. The results of Eberhardt's psychological studies suggest that the general white American population either lacks the basic knowledge or will to learn about race in American society and history. Eberhardt concludes that most white Americans are not concerned at all with race and diminishes importance. Moreover, Eberhardt identifies the negative associations society equates with race and that "race can be processed implicitly" and thinking about race in this manner "has consequences." ${ }^{.55}$ Race is a factor that can influence the public and numerous studies indicate the presence of a white American stereotype labeling blacks as hostile. Despite the government's efforts to provide legal equality, many white Americans associate blacks with crime. Additional scientific trials conducted by Eberhardt indicates that white Americans implicitly dehumanize African-Americans in culture and images. ${ }^{56}$ Implicit racial associations are practiced and reinforced on a daily basis and Civil War reenactments represent an occasion that utilizes a narrow narrative and reflects the shortcomings that Dr. Eberhardt addresses. Eberhardt's analysis applies to reenactments and highlights the causal link between reenactments and negative associations about blacks.

Negative impressions of blacks may implicitly inspire some white men to don a uniform and secure their masculinity. White Americans use reenactments to empower themselves in an evergrowing diverse society and this participation provides a window into the white male's state of mind.

Reenacting can be a useful tool, but not under the guise by which modern reenactments present the Civil War. Azie Mira Dungey recently chronicled her role as a slave reenactor on Mount Vernon for the Washington family in Ask a Slave. In her bitterly comical, yet insightful

\footnotetext{
${ }_{55}^{55}$ Ibid., Dr. Eberhardt's wording during her Cornell University presentation.

${ }^{56}$ Ibid., Paraphrasing of Dr. Eberhardt's observations.
} 
internet series, Dungey notes the American public's ignorance with regards to racial issues: "While most of us claim tirelessly that all questions are good questions no matter how ignorant they seem, this persistent resonance turns a simple lack of knowledge into an expression of insensitivity. ${ }^{, 57}$ Dungey's experiences suggests that "everybody is so proud of what it means to be an American, but...people don't take the time to understand... what's considered a less valuable history, which is African-American history. ${ }^{" 58}$ Moreover, Dungey notes the responsibility that she and other reenactors maintain in communicating to onlookers:

"Reenacting slavery is a delicate business, laced with potential missteps, the consequences of which fall most heavily upon the reenactor-and the greatest difficulties will come from failing to reckon with the present, not the past. ${ }^{, 59}$ Dungey's conclusions directly correlate to modern anxieties of race and masculinity displayed by Civil War reenactments. But is a historical memory that is indicative of unsettled racial and masculine anxieties destined to "crack" and "crumble?"60

In an effort to contribute to and understand the role of Civil War reenactments in society, this work will analyze how reenactments promote Southern notions of masculinity and minimize the role of African-Americans in United States history. The consequence of this narrow memory perpetuates more narrow memories and reflects modern social anxieties. Chapter One will discuss the origins and importance of Civil War reenactments directly following 1865 and the early limitations of those reenactments as seen through preserving memories. Chapter Two will examine why modern reenactments attract white, male participants, while Chapter Three analyzes the use of modern reenactments to celebrate Southern attitudes that the Union sought to

\footnotetext{
${ }^{57}$ Joanne Melish. "[Re]Living Slavery: Ask a Slave and the Pitfalls of Portraying Slavery for the Public," The American Historian, Organization of American Historians (2014): 37.

${ }^{58}$ Ibid., 36.

${ }^{59}$ Ibid., 38 .

${ }^{60}$ Blight, American Oracle, 183.
} 
destroy in the1860s. The fears and anxieties of white males from the South will provide the narrative focus. Finally, the Conclusion will discuss if reenactments are an appropriate historical practice amid a developing twenty-first century American society vexed by racial insecurities and social anxieties.

Amending the incomplete historical memories presented by Civil War reenactments will help the United States come to grips with racial anxieties. Moreover, and perhaps more precisely, reenactments provide a window into a bigger phenomenon. Although reenactments remain socially acceptable and commonplace in both the North and the South as a means of educating the public, the history and messages they convey remain unquestioned. The American public still struggles with notions of race and masculinity, as rancher "Cliven Bundy wonders if blacks are 'Better Off as Slaves' than on government assistance." ${ }^{61}$ Additionally, Dr. Jennifer Eberhardt stresses the importance of addressing racial shortcomings in modern America - and suggests that these conversations "encourage us to think more concretely about the meaning of racial equality" and "ultimately incorporating inequality into antidiscrimination analysis underscores the difficulty of the challenges we face in attempting to refashion the racial legacy of our past." ${ }^{\text {62 }}$ Lastly, although James Gibson refers to Vietnam in his research, modern Civil War reenactments are comparable and are "simultaneously a vision of a social world - the battlefield - and a journey into the psyche." ${ }^{63}$ Reenactments encompass modern issues and anxieties in America, but it has yet to be determined whether or not this narrow historical memory will change to accommodate a broader, more inclusive view of the Civil War and modern American society.

\footnotetext{
${ }^{61}$ Thompson, "Cliven Bundy Wonders if Blacks are 'Better Off as Slaves' than on Gov't Assistance," TalkingPointsMemo, http://talkingpointsmemo.com/livewire/bundy-explains-slavery-remarks.

${ }^{62}$ Banks, Eberhardt, and Ross, "Discrimination and Implicit Bias in a Racially Unequal Society," 1171.

${ }^{63}$ Gibson, Warrior Dreams, 78.
} 


\section{CHAPTER ONE: \\ THE ORIGIN OF REENACTMENTS AND \\ THE MYTH OF THE LOST CAUSE}

\section{Pride and patriotism, not less than gratitude, prompt you to celebrate and to hold it in perpetual remembrance. ${ }^{64}$ \\ - Frederick Douglass \\ (1852)}

Civil War reenactments instill specific images in twenty-first century American minds.

From blue and gray uniforms to stacked rifles and pitched tents - there are physical elements of modern American Civil War reenactments that are undoubtedly intended to replicate accurately the experiences and atmosphere of the War. But why replicate the American Civil War with such physical accuracy and at such exhaustive measures? After 150 years, what do reenactments accomplish? A discussion reviewing the origins of reenactments reveals a history rooted in the pain of a mourning nation seeking to justify sacrifices and, through a veneration of military engagements, commemorate the hundreds of thousands of souls who perished. Historically, reunions prioritized the military aspects of the War, producing and perpetuating myths while underplaying the War's many social and political consequences. This precedent is essential to understanding twenty-first century reenactments and their continued inability to address social questions.

In the years immediately following the War, few veterans or survivors expressed interest in commemorating the dead or organizing reunions. Following years of death and turmoil, Americans who suffered were understandably not eager to return to such unpleasant memories and contemplate the meaning behind the devastation. David Blight says when there was "a first attempt to gather the Blue and the Gray in 1874," it "was abandoned when it became clear that it

\footnotetext{
${ }^{64}$ Edward Ayers, America's War: Talking About the Civil War and Emancipation on their $150^{\text {th }}$ Anniversaries. (Library of Congress: American Library Association, 2012),15.
} 
was simply too early for soldiers to mingle at the scene of such sensitive memories." ${ }^{65}$ There were efforts made as early as the late 1860 s and 1870 s to organize veteran reunions at important battlefields like Gettysburg. ${ }^{66}$ However, returning to the fresh memory of battle was unappealing to a majority of Americans and, moreover, it was difficult "convincing Confederate veterans to come back to the scenes of their failure at Gettysburg." ${ }^{\text {67 }}$ Amongst political divisiveness, economic turmoil, and social anxiety of post-Civil War America, most Americans found any type of reminiscence unappealing. ${ }^{68}$

Drew Gilpin Faust highlights the moral, religious, and psychological constraints that influenced those immediately after the War. ${ }^{69}$ Faust's explains why veterans and a recovering civilian population might have been reluctant to reunite and remember those who had fallen. She notes devastation where, "more than 2 percent of the nation's inhabitants were dead as a direct result of the war," with, "an estimated 620,000 " dead. ${ }^{70}$ Faust stresses the significance of the death toll and explains that this devastation was "the approximate equivalent of the population in 1860 of the state of Maine, more than the entire population of Arkansas or Connecticut, twice the population of Vermont, and more than the whole male population of Georgia or Alabama."71 In 2016 terms the number of fatalities would approximate 6 million. $^{72}$

However, as years passed and Americans began to reflect, more veterans opened up to discussing their experiences. Civil War veterans concerned themselves with returning to the battlefields, honoring fallen comrades, and focusing on the future unity of the nation. Many

\footnotetext{
${ }^{65}$ Blight, Race and Reunion, 202.

${ }^{66}$ Ibid., 188.

${ }^{67}$ Ibid.

${ }^{68}$ This American social anxiety will be discussed in greater detail with regards to modern reenactments and race.

${ }^{69}$ Drew Faust, This Republic of Suffering, Death and the American Civil War (New Yew: Vintage Civil War Library, 2008), 33.

${ }^{70}$ Ibid., 266 and xi.

71 Ibid.

72 Ibid., xi.
} 
fixated on how they and their fallen comrades would be remembered by future American generations. More of a tribute to service and duty, the discussion evolved to less about death and what the War may have been about.

Americans began to commemorate the War and, with that, an American memory of the War was born. As time passed more veterans "were eager to see their names on monuments." ${ }^{\text {,73 }}$ A new reverence for fallen comrades and sacrifice gave way to Decoration Day, which eventually evolved into Memorial Day. ${ }^{74}$ Decoration Day began as an occasion of remembrance to honor the dead and, as seen in Figure 1.1, Americans all over the country memorialized the Civil War by placing flowers at the graves of fallen loved ones and soldiers. The initial reluctance expressed by veterans after the War developed into a willingness to share experiences, but this remembrance was incomplete - few considered the meaning of the War or why it was even fought. Unimaginable numbers of death, paired with a desire to recover what was lost, encouraged a healing America to focus on reunions and prioritize moving forward as a reconciled, united nation. ${ }^{75}$

FIGURE 1.1: Young children adorn graves with flowers at an unidentified location. Decoration Day (1885) by Carl Hirschberg (Private Collection). ${ }^{76}$

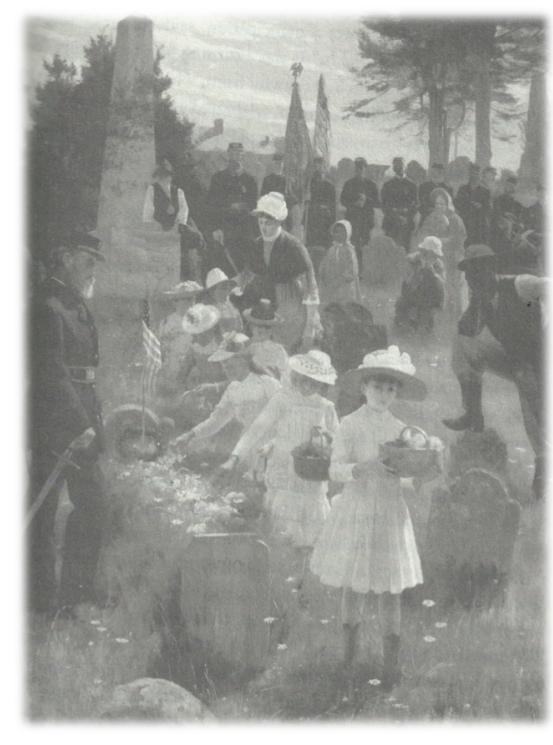

\footnotetext{
${ }^{73}$ Blight, Race and Reunion, 188.

${ }^{74}$ Ibid., 65.

${ }^{75}$ Blight and Faust suggest unprecedented death encouraged the formation of early, limited American memories of the War.

${ }^{76}$ Blight, Race and Reunion, 75.
} 
With a willingness to commemorate the War, both Union and Confederate veterans increasingly expressed interest in reuniting at battlefields to share their experiences and honor fallen soldiers. In Richmond in October of 1875, thousands of Confederate veterans gathered during the unveiling of a statue to honor Stonewall Jackson. ${ }^{77}$ Well into the 1880 s, veterans held more commemorations and, eventually, the events developed into larger community affairs. The reunions started at battlefields and, "sometimes on anniversaries, such as in May 1884 at Fredericksburg, Chancellorsville, and the Wilderness in Virginia." ${ }^{78}$ With each passing year, an increasing number of Americans grew comfortable with commemorating the War. As events grew in size, Americans did not stress the reasons the War was fought, emancipation, or what the future meant for newly freed African-Americans. Instead, consumed with tremendous loss and driven by validation of sacrifice, in the late nineteenth-century the American public concerned itself only with the reunification of their once divided nation.

In 1887 , the nation commemorated the twenty-fourth anniversary of the Battle of Gettysburg. Traveling from cities all over the country to memorialize survivors of both sides, “some five hundred members of the Philadelphia Brigade veterans' organization met at the Pennsylvania town with two hundred members of the Pickett's Division Association from Virginia. “79 Commemorating the Civil War was no longer an exclusive celebration by a few veterans, but was a means by which the nation officially mourned for the dead and reunited veterans. Civil War veterans gathered to share their war, battle, and camp experiences. Figure 1.2 shows twenty-three Confederate veterans posing for their reunion in the $1890 \mathrm{~s}$. The significance of the photo lay not in the occasion, but in how eerily similar the photo compares to any other unit photo taken during the War. Each soldier posed with a rifle and stood in the same

\footnotetext{
${ }^{77}$ Ibid., 80.

${ }_{79}^{78}$ Ibid., 202.

${ }^{79}$ Ibid.
} 
attire that he would have worn thirty-years earlier. Nineteenth century veterans gathered at battlefields in full uniform, prioritized the reunification of the nation, and honored those who died in combat. Moreover, as the photo from 1890 indicates, the veterans of Civil War reunions recreated military experiences prior to the more commonly known reenactments of the twentieth and twenty-first centuries.

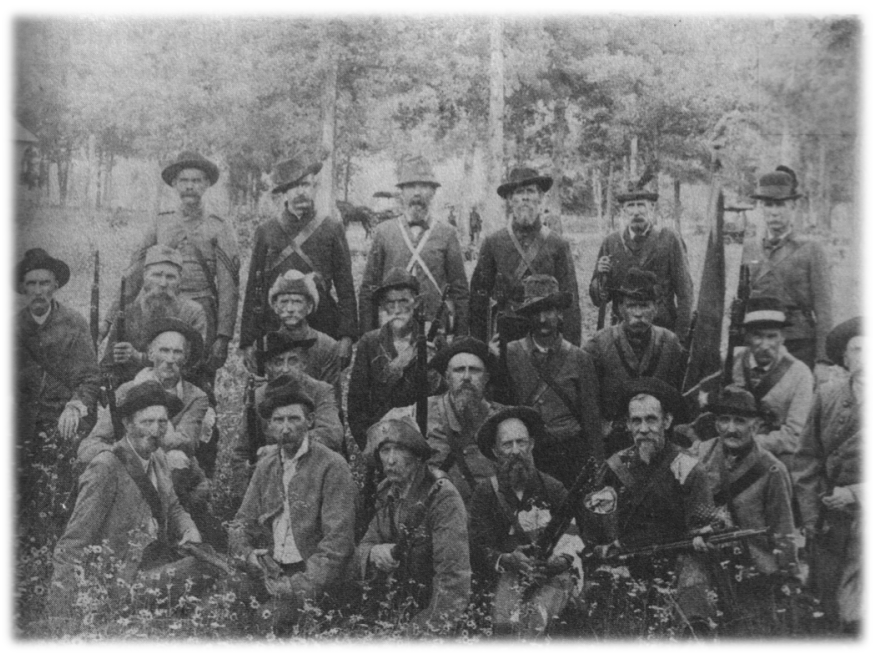

FIGURE 1.2: Confederate veterans pose for a photo at a reunion during the $1890 \mathrm{~s}$. "Old Guard of Richmond" R. E. Lee Camp No. I (The Museum of the Confederacy, Richmond, Virginia). ${ }^{80}$

During the first half of the twentieth century, veterans continued to commemorate the War and, with the passage of time, gave elaborate speeches, staged ornate parades, and organized battlefield visits. The historian Carol Reardon discusses a celebratory atmosphere of brotherly reunion amongst Union and Confederate veterans of the Battle of Gettysburg. She highlights the exhaustive lengths veterans took to commemorate the War and their eagerness to make the ceremonies more significant. Early veterans unveiled new monuments " to commemorate both the first and the second charge of Pickett's Division." ${ }^{81}$ As Civil War veterans grew more comfortable with meeting one another, the frequency and size of the events increased.

\footnotetext{
${ }^{80}$ Blight, Race and Reunion, 191.

${ }^{81}$ Carol Reardon, Pickett's Charge in History and Memory (Chapel Hill and London: The University of North Carolina Press, 1997),194.
} 
Furthermore, Reardon's analysis reveals that veterans advocated for more public works to commemorate soldiers and units in the War. Much of the focus was on memorializing, and there was little, if any, legitimate effort to address the social and culture changes in America brought on by the War. The veterans focused on honoring the sacrifices made in battle. Eventually, those who mourned no longer engaged in a passive role, but formulated and perpetuated myths and memories that appealed to many white Americans who were unwilling to address the racial implications of the War.

As the number of Civil War veterans dwindled, fewer occasions like the one depicted in Figure 1.2 occurred at commemorations. Fewer veterans were alive for reunions and those who might be were no longer healthy enough to make the journey and exchange their experiences, reminisce over battles, and participate in ceremonies. The last Union veteran died in 1956, while the last Confederate passed shortly after in $1959 .{ }^{82}$ However, the passing of the last Civil War veterans did not end the commemoration and honoring of those who died during the War. Decoration Day and, eventually, Memorial Day continued these traditions and ingrained Civil War commemoration to American culture. In the minds of the American public, memory of the War consisted of reverence for the heroic soldiers and battlefields. But how would an American public channel reverence for those who fought in the War without the participation of the actual veterans who engaged in combat?

During the second half of the twentieth century, remembrance emerged in new forms that emphasized the importance of reunion and other military elements of the War. The historian Thomas J. Brown stresses, "One striking development was the rise of the practice of 'reenacting'

\footnotetext{
${ }^{82}$ Terry Jones, Confederates in the Attic Dispatches from the Unfinished Civil War (University of Louisiana: McGraw-Hill Companies), 681.
} 
the experiences of common soldiers." ${ }^{83}$ Just as Civil War veterans were the original reenactors of battles, so too was "the presentation of sentimental scenes of camp life was (also) a favorite activity of veteran's groups. $" 84$ At this point in American memory of the War, the equivalent to modern, twenty-first century reenactments emerged as a means of public commemoration. By the centennial of the Civil War, 1961 - 1965, Americans normalized reenacting and accepted it as a "sophisticated costumed-role playing activity comparable to the personations long familiar at sites like Colonial Williamsburg and Plymouth Plantation." ${ }^{\text {85 }}$ Figure 1.3 displays a photo from the Battle of Gettysburg commemoration in 1963. Reardon's research confirms not all reenactments were received well by audiences: “At 3 P.M. on July 3, 1963, nearly 30,000 spectators watched 500 men...joined 'in brotherhood and amity to pledge their devotion to the symbol of their common unity - the Stars and Stripes.' Many spectators agreed that the ceremony lacked dignity." 86 The issue for many white Americans was that the events neglected the details of battle and failed to honor the dead. A lack of public enthusiasm yields insight into the authenticity of early reenactments and the questionable relevance of re-waging battles without their original veterans.

\footnotetext{
${ }^{83}$ Thomas Brown, The Public Art of Civil War Commemoration (Boston and New York: Bedford/St. Martin's, 2004), 50.

${ }^{84}$ Ibid.

${ }^{85}$ Ibid.

${ }^{86}$ Reardon, Pickett's Charge, 208.
} 


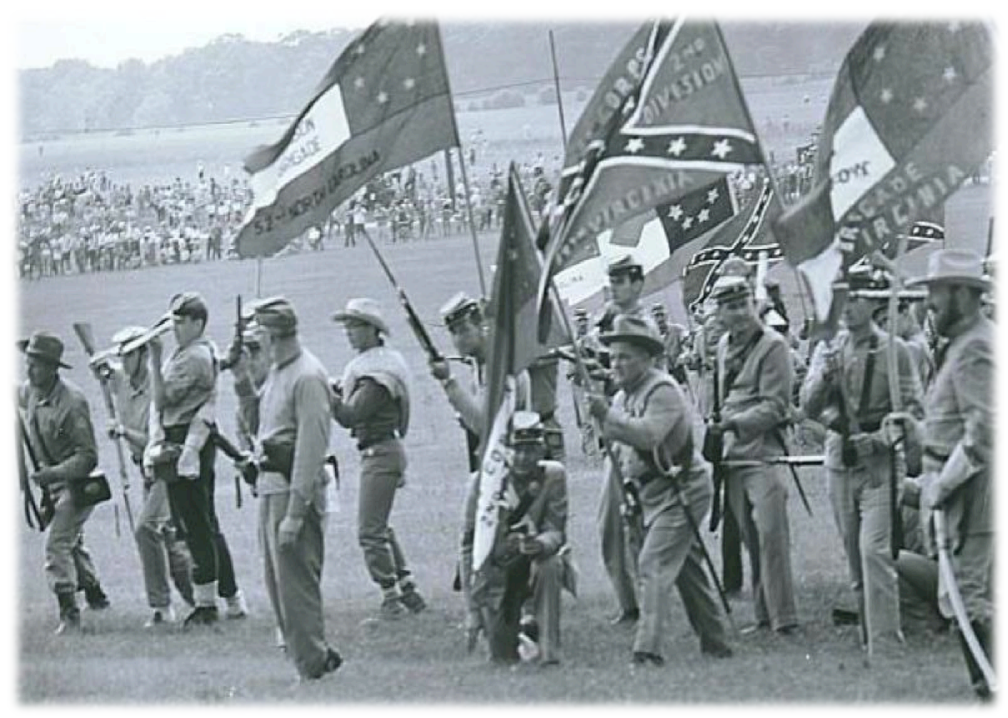

FIGURE 1.3: Photo of Commemoration of Pickett's Charge, 1963 (National Park Service, U.S. Department of Interior). ${ }^{87}$

Although reenactments gradually increased in popularity, some spectators labeled reenactments as disrespectful. Comparing Figure 1.3 to Figure 1.2, the legitimate, rustic, worn look of the veterans was replaced by the pageantry of a different generation. Perceived by the general public as dishonorable, the practice started off slowly until the American Revolution Bicentennial of 1976-1983 occurred in conjunction with the $125^{\text {th }}$ Anniversary of the Civil War. ${ }^{88}$ Over time and with public exposure, Civil War reenactments merged with the interests of amateur historians, hobbyists, and out-door enthusiasts. Reenactments no longer represented commemorations by veterans, but became an acceptable, casual hobby. ${ }^{89}$ Moreover, Brown notes that "it was no coincidence that Confederate reenactors vastly outnumbered Union reenactors, as remembrance of the Confederate common soldier flourished in other forms as well." 90 The white men who reenact are attracted by nineteenth century Southern, Confederate

\footnotetext{
${ }^{87}$ National Park Service, "1963 Commemoration of Pickett's Charge" (U.S. Department of the Interior: July 3, 1963). URL: http://www.nps.gov/media/photo/gallery.htm?id=C78A0AA0-155D-451F-6792278A97619590.

${ }^{88}$ Brown, Civil War Commemoration, 50.

${ }^{89} \mathrm{Ibid}$.

${ }^{90}$ Ibid.
} 
attitudes - a topic to be discussed in further detail later. With growing interest nationwide by 1998, an estimated 40,000 Americans engaged in reenactments, which was a "rapidly growing hobby of (the) Civil War."91 Although modern reenacting numbers are now closer to 30,000, the practice remains popular in twenty-first century America.

Rather than contemplate why the War was fought, reenactors focused on honoring the dead. As a result, both directly and indirectly, a number of memories and myths perpetuated alternative narratives of the Civil War and detracted from essential issues requiring national attention. For the purposes of this modern analysis, the two prevailing memories include the Lost Cause Myth and the Reconciliation Memory. ${ }^{92}$ Both of these memories developed and circulated after the War when veterans, and later hobbyists, reenacted wartime combat. The hobbyists in particular, focused exclusively on the details of battles and generals. The commemoration of battles sensationalized the role of those who fought and remained the focus for the majority of white Americans. Reenactments are a historical byproduct of this biased perspective. Reenactments embody the legacy of these memories and, therefore, sustain the same distortion of history. An understanding of Civil War memories reinforces the concept that reenactments continue modern legacies of limited memories and, in doing so, perpetuate narrow views of race and sustain nineteenth century masculinity.

As a result of American memory evolving out of national mourning and devastation, a post-War America desired a recent history and future memory that was acceptable. William Barney analyzes Confederate memory and suggests that memory and the War are fundamentally linked: "Memory, as a host of recent studies has shown, is never fixed," it is "a static

\footnotetext{
91 Ibid.

${ }^{92}$ Many historians have referenced Civil War memory, but credit here is attributed with David Blight's Race and Reunion where he references both the Lost Cause and a Reconciliation Memory throughout his analysis.
} 
remembrance of a commonly agreed on set of experiences. ${ }^{93}$ Barney addresses the censorship of memory and suggests "memory, both for individuals and for cultures, is an active and selective process of constructing the past as noteworthy for what is forgotten as well as what is chosen to be remembered and celebrated." ${ }^{, 4}$ Furthermore, Barney recognizes that, as a result of "a tie of shared trauma that destroys or radically alters the patterns of life that had sustained old traditions," Americans wanted to make sense of the carnage and embraced the "need for a collective identity to bind together and define a group. ${ }^{, 95}$ Unprecedented death and a demand to mend this trauma guided Americans and influenced the formation of Civil War memories that omitted the realties of a post-War America that required social healing for all Americans - not just white Americans. Understanding early memories of the War reveals important narratives and underscores the narrow history rooted in, and portrayed, at reenactments.

David Blight suggests that, although memory after the War was rooted in national mourning, very little attention was ever afforded to the causes or consequences of the conflict. Blight highlights cultural changes as Americans began to mourn less and plant the early seeds for their own revisionist histories. The Lost Cause emerged as the main vision of the War and paved the way for a Reconciliation Memory in which the former Confederacy began to construct a new and useable history. Although commemorations began as an innocent, passive form of mourning, by "the 1890 s, Confederate memories no longer swelled as much on mourning or explaining defeat; they offered a set of conservative traditions by which the entire country could gird itself against racial, political, and industrial disorder." ${ }^{96}$ In the formation of American Civil War memory, it is evident as early as 1890 that American memory avoided the social and racial

\footnotetext{
${ }^{93}$ Barney, The Making of a Confederate, Walter Lenoir's Civil War (Oxford University Press: 2008), 224-225.

${ }^{94}$ Ibid., Barney cites and backs up his claims with research with regards to the construction of memory.

${ }_{95}^{95}$ Barney, Making of a Confederate, 224-225.

${ }^{96}$ Blight, Race and Reunion, 266.
} 
consequences of the War by directly combating the very traditions overturned by the end of the War.

A Lost Cause Myth offered an alternative history to a battered South desperate for any sense of pride. The Lost Cause focused on certain overarching principles - without questioning the validity or historical legitimacy of these memories. First, the Lost Cause suggested that secession was legal and the Confederacy was right to secede. Second, the Myth glorified a Confederacy that was fighting for self-governance, not slavery. And lastly, the Myth assumed the Confederacy fought against insurmountable odds and, although lost, the War was justified through its valiant efforts. Instead of confronting the failures of War or any of the social consequences, "by the sheer virtue of losing heroically, the Confederate soldier provided a model of masculine devotion and courage in an age of gender anxieties and ruthless material striving."${ }^{.97}$ The Lost Cause attempted to overturn the results of the War and successfully flourished "in the 1880s" where Americans "digested the soldiers' literature of reunion in magazines and memoirs along with the evolving Lost Cause mythology." ${ }^{98}$ White, Southern men fought to preserve a romantic history as "diehards fashioned a historical creed, demanded discipleship, and worked with urgency to counter Northern histories." ${ }^{.99}$ Support for the Lost Cause increased overtime as the South fought to "reclaim its influence in sectional and national affairs," and "to convince Southern whites, and eventually Northerners as well, that the South had fought for a worthy cause and that Confederate leaders had been justified in their actions." ${ }^{, 100}$

While the earlier commemorative gatherings and unveilings created an atmosphere to exchange ideas and promote Southern traditions, the Lost Cause Myth eventually evolved into a

\footnotetext{
${ }^{97}$ Ibid.

${ }^{98}$ Ibid.

${ }^{99}$ Ibid., 262.

${ }^{100}$ Barney, Making of a Confederate, 225.
} 
united, national effort to reconcile white Americans. As American memory accepted the Lost Cause, it continued to transform the narratives of the War and "like all great mythologies, the Lost Cause changed with succeeding generations and shifting political circumstances."101 The Lost Cause survived as the integral foundation of memory, redefining Southern political, social, and moral history after the Civil War. It featured an ability to adapt and transform the narratives of the Civil War into useable histories that highlighted a defeated, yet proud Confederacy. Moreover, by the 1890 s and well in the twentieth century, the Myth emphasized a memory of reconciliation.

This Reconciliation Memory stressed reunion and presented a history by which a victorious North and a defeated South met at commemorations, bonded, and healed over their mutual experiences of the War. Figure 1.4 depicts a typical scene of Civil War reunions in the early twentieth century and highlights a theme of reconciliation. The significance rests in what is not depicted at the commemoration ceremony. As veterans returned to battlefields they no longer concentrated on their sorrow. With their return, veterans and observers failed to consider any form of healthy debate over the causes of the War, what the War meant for former slaves, or how their efforts changed the nation. Rather, post-War America is best represented through the simple handshake of Figure 1.4 and that is it. In time, "the Lost Cause became an integral part of national reconciliation by dint of sheer sentimentalism, by political argument, and by recurrent celebrations and rituals."102 The emergence of a Reconciliation Memory presented a history that, both Northern and Southern, white men applauded and embraced. It was a history that all white Americans could endorse because it exclusively glorified the efforts of other white males.

\footnotetext{
${ }^{101}$ Ibid., 266.

102 Ibid.
} 


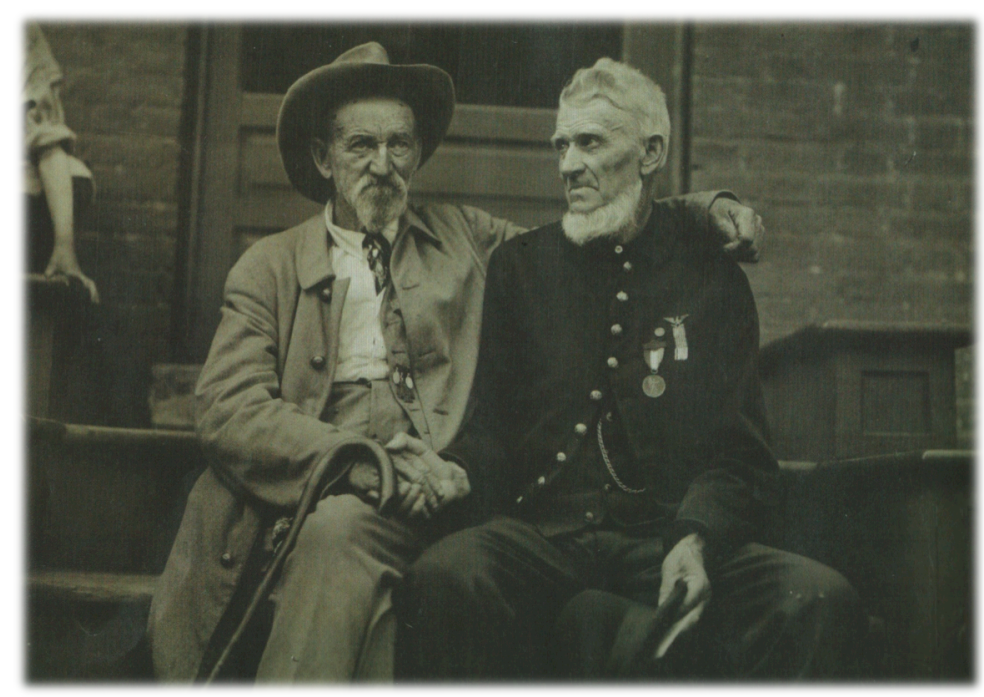

FIGURE 1.4: At the Fiftieth Anniversary of the Battle of Gettysburg, a Southern veteran and Northern veteran shakes hands. The battle of 1863 is something of the past and reunion is at the forefront of the nation's mind. (Time Life Magazine, 2016). ${ }^{103}$

If the Lost Cause distracted Americans from addressing the social implications of the War by glorifying Southern efforts, the Reconciliation Memory sustained these shortcomings by emphasizing the post-War friendship of white Americans for the entire nation. This friendship between former foes, underscored a shared experience of combat, and consciously omitted debates over the causes of the War or any consideration of newly freed slaves. White Americans ignored race and slavery and emphasized the heroic and valiant sacrifices made by both Northern and Southern soldiers. Northern and Southern whites turned to a Reconciliation Memory that glorified the role of white men in the War and neglected any issues of race. Whether or not individuals consciously chose these narrow narratives, the failure to address the critical social and racial implications of the War only reinforced a Reconciliation Memory in American memory. By the early nineteenth century, Americans favored the Reconciliation Memory as

\footnotetext{
${ }^{103}$ Time Life magazine, The Civil War on the Front Lines, From Fort Sumter to Appomattox (Time Inc. Books: 2016), 90.
} 
commemorations continued as standard traditions by which Americans remembered the War through a mutual regard for unity. For example, by the Fiftieth Anniversary of the Battle of Gettysburg in 1913, the memory and history of the War celebrated white brothers who fought one another. Figure 1.5 demonstrates how reconciliation dominated Civil War memory and received national attention. Both Union and Confederate veterans shook hands over the same stonewalls where blood spilt fifty years earlier. Fifty years after the War, an exchange of hands between former enemies symbolized the authority of the Reconciliation Memory. Additionally, reunions between veterans emerged as popular, public spectacles to honor the sacrifices of both Union and Confederate soldiers. Reinforced by the Philadelphia Brigade Association and the Pickett's Division Association shown in Figure 1.5, veterans organized and consciously structured a post-War narrative glorifying their efforts. Aside from the large crowds of spectators, Americans from all over the country viewed and discussed the photographs and events at commemorations and reunions. ${ }^{104}$ Reconciliation Memory dominated the Civil War narrative, but continued to fall short of tackling any of the critical issues that remained unaddressed at War's end. David Blight underscores the shortcomings of reconciliation and states that "naturally, monuments and reunions had always combined remembrance with healing and, therefore, with forgetting." ${ }^{, 105}$ White Americans skipped any self-reflection or examination of the consequences of the War and, instead, decided to heal and construct a history that celebrated white heroism.

\footnotetext{
${ }^{104}$ Blight, Race and Reunion, 389.

${ }^{105}$ Ibid.
} 


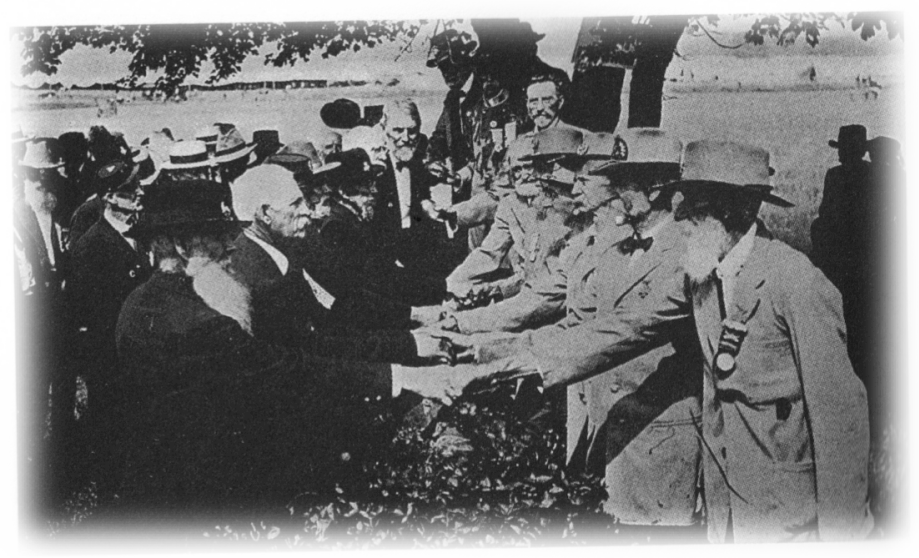

FIGURE 1.5: "Pickett's Virginians and Webb's Pennsylvanians shake hands at the stone wall, July 1913" (Fiftieth Anniversary of the Battle of Gettysburg). ${ }^{106}$

The Fiftieth Anniversary of the Battle of Gettysburg represented the success of the Lost Cause supporters who, through both organized and individual effort, aimed to rewrite the Civil War narrative of the American South. Moreover, a Reconciliation Memory misdirected attention away from the racial consequences of the War. An alternative narrative encouraged white Americans to reconcile. Blight says, "Not out of overt conspiracy, not by subterfuge alone, did white supremacist memory combine with reconciliation to dominate how most Americans viewed the War."107 Reinforced by Figure 1.6, Blight confirms a direct connection between racism in post-War America and the Reconciliation Memory, as President Woodrow Wilson defined the War as a "quarrel forgotten." 108 President Wilson stood on the same battlefield where President Lincoln addressed a weary nation in 1863 and preached the birth of a new freedom. Unlike Lincoln, Wilson was unable to see through the failings of his time. Wilson focused on white men and ignored African American contributions. In the context of the early twentieth century, President Wilson failed to bring forth pertinent issues regarding the War. He, like so many other Americans, was a product of his time. Wilson's remarks focused on a

\footnotetext{
${ }^{106}$ Reardon, Pickett's Charge, 194.

${ }^{107}$ Blight, Race and Reunion, 389-390.

${ }^{108}$ Ibid., 10.
} 
reunion "to celebrate the end of all feeling as well as the end of all strife between the sections." ${ }^{109}$ At a time when racial discrimination was at its height, Wilson's remarks contributed to a Reconciliation Memory that omitted African American narrative and reinforced a limited vision of the War for future generations.

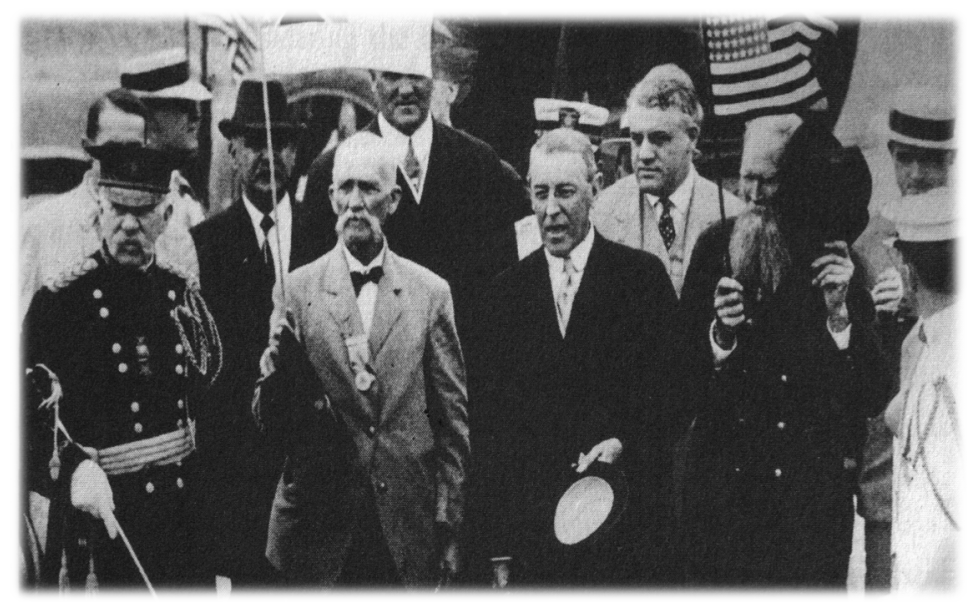

FIGURE 1.6: Woodrow Wilson speaks at the Fiftieth Anniversary of Gettysburg during a reunion on July 4, 1913. President Wilson was the first Southerner to be elected to the U.S. Presidency since before the Civil War (Record Group 25, Pennsylvania State Archives). ${ }^{110}$

President Wilson's remarks at the Fiftieth Gettysburg Anniversary attest to the early prevalence of a misguided and misrepresented memory, propagated by a white America dedicated to the glorification of its own historical narratives through reunions and commemorations. Moreover, the formation of this imperfect memory was not just a product of the Civil War, but the "mythology was the product of fifty years of cultural evolution, of the growth and erosion of memories in response to events and social tensions." ${ }^{\text {"11 }}$ The social and racial tensions of the post-War era stressed the reunification of white America and the exclusion of disenfranchised African Americans. War commemorations, veteran reunions, and reenactments all supported this partial memory and are the primary means by which many

\footnotetext{
${ }^{109}$ Ibid., 7-8.

${ }^{110}$ Ibid.

${ }^{111}$ Ibid., 390.
} 
Americans learned and passed on memories of the War. These traditions continued as popular history based in collective memories, symbolic of the American Civil War and those who heroically fought. American memory and the way in which Americans processed the War grew into, as Blight notes, a "national ritual in which the ghost of slavery, the very questions of cause and consequence, might be exorcised once and for all - and an epic conflict among whites elevated into national mythology."

If early commemorations emphasized combat and limited memories of the War, it is wise to ask if modern twenty-first century reenactments continue this legacy. It is necessary to explore if modern reenactments sustained a similar overemphasis on combat and retained myths and memories of the early twentieth century. A deeper understanding of modern reenactments sets the foundations for discussions of race and anxiety in twenty-first century America.

${ }^{112}$ Ibid. 


\section{CHAPTER TWO: \\ THE POLITICS OF REENACTMENTS}

How complete the union has become and how dear to all of us, how unquestioned, how benign and majestic, as state after state has been added to this, our great family of free men! $!^{113}$

\section{- President Woodrow Wilson \\ (Fiftieth Anniversary of Gettysburg, 1913)}

Across twentieth-century America, the majority of a misinformed population subscribed to the Civil War myths and memories of commemorative reunions. As milestones like the Fiftieth Anniversary of the Battle of Gettysburg solidified the presence of this reunion memory in American history, the public lost sight of emancipation for African Americans. White Americans employed a selective history that ignored the role of African Americans before and after the War. This history glorified white brotherhood in battle at the exclusion of significant racial implications. Regardless of the 150 years that have passed since War's end, modern Civil War reenactments perpetuate and promote the same ideas constructed during earlier reunions. Blight says that racial and other social issues continue to be overlooked as modern reenactments stress a white history with, "important aspects of the era, using closely-authentic weapons, clothing, tools, tents, language, customs and ideals of the people of that time."114

Before considering reenactments any further, it is crucial to discuss those who reenact:

the twenty-first century white, male reenactor. Out of the dozens of reenactors asked for interviews, most refused to reveal names and would not reveal their occupation. The reenactors who were willing to share during a three-week excursion are mentioned in this thesis. ${ }^{115}$ However, the general reluctance others showed to discuss race and masculinity is in response to,

\footnotetext{
${ }^{113}$ Blight, Race and Reunion, 11.

${ }^{114}$ Civil War Reenactment Society (“Welcome” Page, January 25, 2015).

URL: http://www.cwrs.info/Civil_War_Reenactment_Society/Home.html

${ }^{115}$ Austin English, Visited Civil War Battlefields in PA, VA, and MD in April of 2013, aenglish@sandiego.edu.
} 
what Christopher Bates suggests, is the "stereotyping" of Southern history as racist. ${ }^{116}$ Bates cites a number of national publications, specifically the Washington Post, depicting reenactments as events full of racist rhetoric. ${ }^{117} \mathrm{He}$ argues modern society portrays reenactors in a negative light and as Southern rednecks of the, "right-wing neo-Confederate movement." identifies negative stereotypes seen in Civil War media about reenactors, and, he posits that this stigma makes reenactors defensive in response to academic inquiries. Although he arrives at conclusions different from this thesis, Bates' research and data on reenactors reveals the specific demographics of modern reenactments.

According to Bates, "anthropologist Cathy Stanton...says 20,000," reenact across the United States, while his other sources suggest about one million participate. ${ }^{119}$ Bates notes the stark contrast between figures in order to highlight that there is no official, standardized method to track and record participation. Nonetheless, Bates concludes that there are enough modern individuals reenacting that the, "modern community is large enough and distinct enough to be very visible." ${ }^{120}$ He says modern reenactments occur in all fifty states as well as in a number of foreign countries. ${ }^{121}$ Moreover, he identifies the minority participation of African Americans. ${ }^{122}$ It is most essential to identify the white, male majority at modern reenactments to set up the foundations for discussions of white masculinity and anxiety in modern America.

The research of Bates and others, like Patricia Davis, confirms that whites make up more than ninety-five percent of the participants. ${ }^{123}$ A majority of these white men were born from

\footnotetext{
${ }^{116}$ Bates, What They Fight For, 119.

${ }^{117}$ Ibid., 112.

118 Ibid.

${ }^{119}$ Ibid., 5.

${ }^{120}$ Ibid., 6.

${ }^{121}$ Ibid., 110

122 Ibid.

${ }^{123}$ Patricia Davis, "More than History and Dates: Black Civil War Re-Enactors Re-Enact Freedom" lecture notes (San Diego Central Library: Joan A Irwin Jacobs Common, March 2, 2015).
} 
1940 to 1960 and grew up with popular culture defining the War through the Lost Cause and Reconciliation Memory. ${ }^{124}$ Of this modern, white majority, "roughly two-thirds of reenactors portray Southerners... with Confederate outnumbering Federal reenactors about 2-to1....essentially the inverse of the actual Civil War." ${ }^{125}$ Bates fails to recognize the historical, racial, and social shortcomings of these historical inaccuracies at modern reenactments. Instead of acknowledging the failures of shortsighted myths, Bates asserts there are noteworthy although limited in quantity - minorities at modern reenactments and casually notes that, "only Massachusetts is known to have more Union (soldiers) than Confederates," as a result of a large African-American presence. ${ }^{126}$ A white, middle-aged, "gun hobbyist" inspired, Confederate majority defines the majority of reenactors. ${ }^{127}$

Bates' analysis of reenactments falls short of recognizing the value of his research. Of all the reenactors Bates interviews, "less than 50 percent of reenactors...argued that the Civil War was caused by an issue or issues other than slavery." "28 Again, although a useful statistic, Bates cites that white reenactors identify the War with, "issues others than slavery," similar to the $42 \%$ of the general American population whom also define the War without slavery. ${ }^{129}$ Bates defends reenactors and those who avoid issues of slavery as mainstream ideas that should be ignored because they tend, "to be very uncomfortable (encounters) for both those playing the role and those witnessing the performance." ${ }^{130}$ However, the Lost Cause Myth and Reconciliation Memory pervasively influence American culture and, the fact remains that slavery is what the Civil War was about - regardless of what some American might believe. The entire issue under

\footnotetext{
$\overline{124}$ Bates, What They Fight For, 110.

125 Ibid., 104.

${ }^{126}$ Ibid.

${ }^{127}$ Ibid., 109.

${ }^{128}$ Ibid., 132.

${ }^{129}$ Ibid.

${ }^{130}$ Ibid.
} 
contention - reenactors and why they fight - is justified by Bates as collective history and avoids racial questions. Bates also fails to see the advantages of alternative forms of reenacting, "as slave reenactment tends to be very uncomfortable for both those playing the role and those witnessing the performance." ${ }^{\prime 131}$ To be discussed in further detail, modern slave reenactors provide a positive, unique, informative experience that is often impressionable because it, in fact, does form uncomfortable conversations about race in America. Instead of confronting the uncomfortable issues of history, Bates identifies reenactments as an "escape" and an "immersive experience that allow(s) them to imagine themselves living, however briefly, in a past time."132 The harmlessness is what establishes the potential impact.

While he downplays this as a harmless hobby, it is this escape that permits white reenactors to recreate a version of the Civil War where nineteenth century white men dominate. Bates' research classifies, "most reenactors" as, "solidly middle class, if not wealthier," but many portray soldiers or poor civilians when reenacting. ${ }^{133}$ He states that, "most reenactors are graying, and yet portray young men and women," and, "high-ranking officers at reenactments tend to have fairly low-level jobs in their civil lives, while many privates and corporals occupy positions of great authority once they leave the battlefield." 134 Bates identifies the escape at modern reenactments, but fails to recognize how reenactments sustain a nineteenth-century white masculinity and ignore critical racial issues in replace of military details. The abundance of attention assigned to the accuracy of battle maneuvers and attire by twenty-first century reenactors echoes the glorified sentiments of War veterans at earlier, twentieth century

\footnotetext{
${ }^{131}$ Ibid.

${ }^{132}$ Ibid., 177.

${ }^{133}$ Ibid., 180.

${ }^{134}$ Ibid.
} 
commemorative reunions. At earlier War reunions, veterans relied on "self-serving exaggeration," and "told of heroism and sometimes (even) of defeat and loss."135

Modern reenactments continue to focus on the soldier's appearance and the physical, martial, aspects of the War. Figure 2.1 shows the Union troops at the Battle of Vista in San Diego, CA in 2013 as they approach Confederate reenactors. There are a variety of elements to grasp from the reenactors at the Battle of Vista. First, reenactors of the battle spare no expense. From a period-rifle to the uniform and accompanying camp equipment - reenactors spend up to thousands of dollars, making every effort to recreate the physical elements of the War. ${ }^{136}$ The cost is a further indication of the lengths taken to recreate the War and sensationalize the role of those who fought it. Likewise, the reenactors of Figure 2.1 bear the flag of a specific unit. Both as individuals and as a larger unit, reenactors re-live the experiences of soldiers in the field.

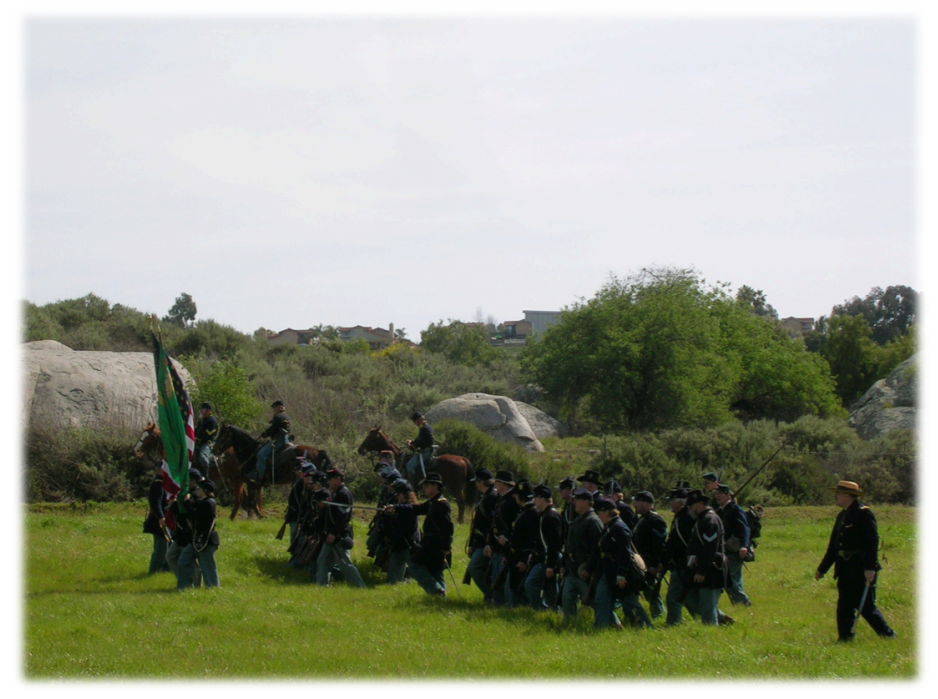

FIGURE 2.1: Performed yearly in Vista, California, the Battle of Vista is a Southern California reenactment of soldiers, cavalry, and artillery (Photograph taken by Austin English on March 17, 2011). ${ }^{137}$

Furthermore, how exact and precise are some reenactments when many fall short of conveying the historical significance of an authentic battlefield? Although reenactors go to great

\footnotetext{
${ }^{135}$ Blight, Race and Reunion, 188.

${ }^{136}$ Speaking with both Sgt. Petzolt and Union reenactor George Horning Jr., Oral Interview on April 6, 2013. Reference Bibliography for full citation.

${ }^{137}$ Battle of Vista Reenactment: San Diego, California (March 17, 2011).
} 
effort into recreating the experiences of soldiers, it is difficult to argue that campaigning across an empty lot in Vista, California pertains to any larger Civil War significance. However, this is not to suggest that all modern reenactments occur on authentic battlefields. The occurrence of reenactments, around the country and regardless of battlefield authenticity, reinforces the notion that modern reenactments continue a legacy that prioritizes solider narratives over other issues that define the War. Promoting the sensationalized legacy of veterans, modern reenactors continue to reenact at authentic battlefields with scrupulous detail, from the unit sizes to brigade movements.

Figure 2.2, similar to Figure 2.1, shows Confederate reenactors engaging their Union counterparts at the Battle of Vista in Southern California. First, Figure 2.1 reveals the extent to which reenactors attempt to authentic experience. Such attention to detail in costume and accessories consumes a large portion of reenactor efforts. The Confederate reenactors of Figure 2.2 purposely purchase attire to look like the torn, worn, and dirty soldiers they strive to honor through shared experience. Lastly, Figure 2.2 clarifies how incredibly close both the Union and Confederate reenactors are on the small plot of land. If Figure 2.1 and 2.2 were placed next to one another, only about 30 feet needs to be accounted for on the battlefield between the units. Opposing artillery units would never have been so close without decimating both friend and foe who stood in close proximity. The historian David Miller - as cannons blasted closely behind each unit and horses lumbered back and forth the small plot - declared at the reenactment, "We'd all be blown away, audience included, if all this happened right here." ${ }^{, 138}$ Dr. Miller's observations attest to the overemphasis reenactments place on the accuracy of combat experience vs. the accuracy of historical narrative. The correct battlefield size or not - some reenactors just

\footnotetext{
${ }^{138}$ Stated by Dr. David Miller of the University of San Diego (San Diego, California: Battle of Vista Reenactment on April 23, 2015).
} 
want to reenact and honor those who fought in the War. As a result, reenactments might fall short of portraying an inclusive history or even realistic combat scenarios at times. Therefore, if reenactors do not portray accurate depictions of the War, there must be a reason or motivation beyond authenticity for those white men who participate in twenty-first century reenactments. Many Confederate reenactors speak, "a lot about honor. They tended to die dramatically, and people would clap and cheer when they did," noted a volunteer. ${ }^{139}$

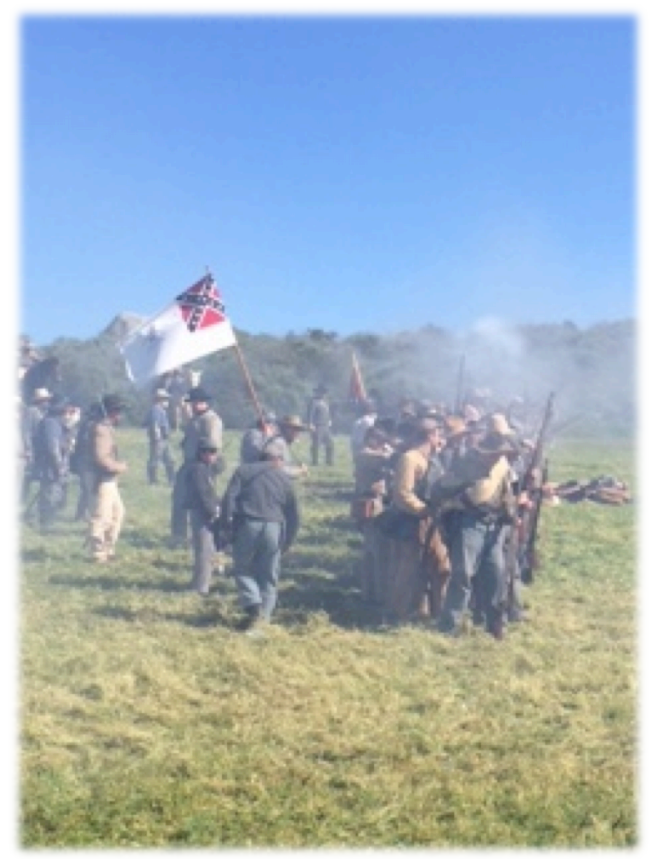

FIGURE 2.2: Confederate unit at the Battle of Vista in Southern California (Photograph by Austin English on April 23, 2015). ${ }^{140}$

As the battlefield at Vista ended with smoke and dozens of bodies rested on the ground, audiences awaited the blast of a bugle that allowed reenactors to quit playing dead, inviting thunderous applause. However, what were audiences applauding for and, more importantly, what was learned from the reenactment? Accurate attire and accessories emphasize the shared experiences of soldiers and physical elements of combat that earlier reunions commemorated. Doing so for a twenty-first century audience reveals a simplistic representation of the War as

\footnotetext{
${ }^{139}$ Emma Doolittle. Civil War Reenactment volunteer in Duncan Mills from 2006-2009 (January 29, 2015).

${ }^{140}$ Battle of Vista Reenactment: San Diego, California (April 23, 2015).
} 
seen by white soldiers. Moreover, the Union and Confederate troops of Figures 2.1 and 2.2 switched sides on the battlefield every afternoon. With this change in location, the reenactors of the Battle of Vista swapped the roles of winners and losers. Johnny Reb became Billy Yank, and Billy Yank became Johnny Reb. Reenactors offered no explanation for the switch other than one Confederate reenactor commented, "It's nice to win every now and then." battlefield is not something that every outgoing reenactor lives around or can travel to every year. As a result, it is not an atypical scenario for reenactors to assemble on sites far from historic battlefields. By switching sides and letting both Union and Confederate units win and lose, the reenactments of southern California and other such locations perpetuate the Reconciliation Memory for a modern audience.

Similarly, and pictured in Figure 2.3, modern reenactments normalize a distorted context of the War. It is not uncommon for the hosting location to request a fee to support future events. However, the significance of Figure 2.3 is introduced to spectators upon payment. The sign advertises the time frame of Civil War reenactments and prepares spectators to go "back to 1863 " with reenactors. ${ }^{142}$ Limiting the conflict to 1863 provides spectators and those who want to learn about the War with a deficient understanding. When a reenactment restricts the time frame by which spectators perceive and process the Civil War, it sustains the flawed memories of earlier commemorations by omitting causes, changes over time, and consequences. In the imagined context of 1863, modern reenactors do not have to confront issues regarding society, race, or even who won or lost the War. Modern reenactors, like the veterans who came before them, preserve a reunion memory that exclusively glorifies white men.

\footnotetext{
${ }^{141}$ Stated by a reenactor in passing at the Battle of Vista Reenactment on April 23, 2015.

${ }^{142}$ Battle of Vista Reenactment: San Diego, California (April 23, 2015).
} 


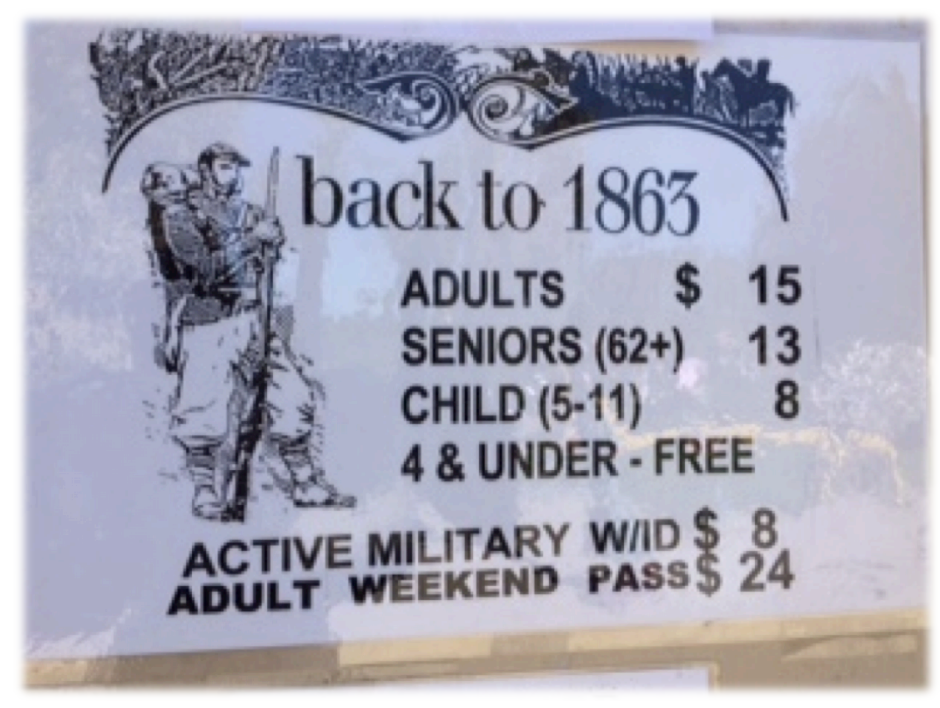

FIGURE 2.3: Civil War Reenactments often come with a charge for admission. At entry, participants and spectators abandon racial and social concerns of the War - it is 1863 so social issues need not be addressed. A restricted time frame encourages an American memory of the War that omits critical issues. This sign was located outside the ticket booth at the Vista reenactment in Southern California (Photograph by Austin English on April 23, 2015). ${ }^{143}$

Many Living Historians represent specific soldiers, generals, leaders, or other popular figures of the War. ${ }^{144}$ For most Living Historians at reenactments, the ultimate goal is to "share with you and pique your interest in the American Civil War," and if either succeeds, they "accomplished (their) mission."145 The mission statement of the Civil War Reenactment Society (CWRS) summarizes the shortcomings of reenactors and Living Historians, alike: "We've been researching, reliving, and relaying the American Civil War for more than 30 years!"146 The CWRS defines the parameters of the Civil War by white males who fought and relaying those individual experiences.

Similarly, Living Historians, exemplified in Figure 2.4, capture the details of individualized characters, further sustaining an understanding and memory of the War as defined

\footnotetext{
143 Ibid.

${ }^{144}$ Civilwartraveler.com, Displays a number of references to participate in or view Living History.

${ }^{145}$ Civil War Reenactment Society website, http://www.cwrs.info/Civil_War_Reenactment_Society/Home.html. ${ }^{146}$ Ibid.
} 
by the white men who fought it. Figure 2.4 underscores a variety of limitations present at modern reenactments. Appearing in meticulous costumes, the Living Historians perform as the quintessential figures Americans often use to imagine the War. These Living Historians embody a Reconciliation Memory that focuses on the individual soldier. An emphasis on their leadership, strategic command, and life experiences are amongst the details that Living Historians commit to memory in order to preserve as accurate of a portrayal as possible. Beyond the elements of combat, these Living Historians fully embrace the character of specific, significant figures. However, the very presence and presentation of specific leaders restricts the way reenactors relay Civil War history to visitors.

Although these Living Historians believe in the importance of their roles to the Civil War, they represent the views of white men. At Vista, the one Living Historian who prompts conversation regarding race in Figure 2.4, dressed as President Lincoln, was murdered at the conclusion of the War, leaving little conversation to be had regarding plans for African Americans after the War. Instead of representing a diverse viewpoint, the reenactors of Figure 2.4 prioritize the narratives of white men like President Lincoln's bodyguard, John Frederick Parker. Living Historians portraying the commanders and leaders at reenactments continue to misrepresent Civil War history through exclusively white narratives. Likewise, Living Historian, "Sgt. Petzolt," embodies the entrenched and normalized flaws of modern reenactments, as he "no longer participate(s)," and instead does, "living History in uniform.,"147

\footnotetext{
${ }^{147}$ Interview with “Living Historian” Sgt. Petzolt: Gettysburg, PA, July 25, 2013.
} 


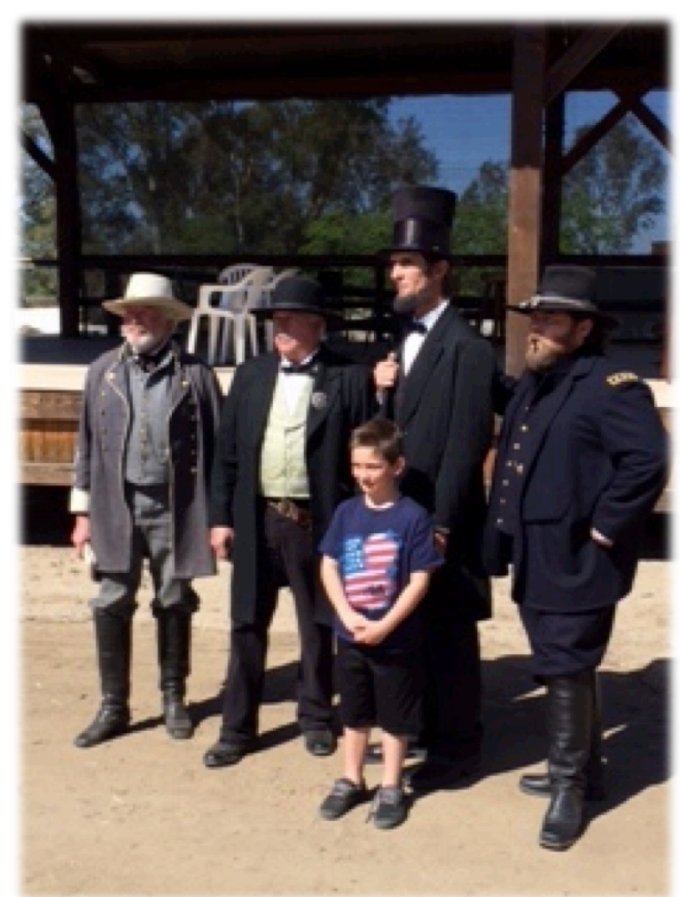

FIGURE 2.4: Reenactments often showcase the leaders and generals of the War. From Left to Right: General Robert E. Lee, John Frederick Parker, President Abraham Lincoln, and General Ulysses S. Grant (Photograph by Austin English at the Battle of Vista Reenactment, San Diego, California on April 23, 2015). ${ }^{148}$

Approaching the summit of Little Round Top and overlooking Devil's Den at the Gettysburg National Battlefield, visitors spot on occasion Living Historian, Sgt. Petzolt. Sgt. Petzolt, as depicted in Figure 2.5, claims to be separate from reenactments and the efforts of other Living Historians, but by every appearance and effort, Sgt. Petzolt is a Living Historian. ${ }^{149}$ It is also important to note Sgt. Petzolt "no longer" participates in reenactments. However, this prior experience parallels the limitations of Living Historians at reenactments and is reflected through his embodiment of a Union soldier atop Little Round Top. On approach to Little Round Top, Sgt. Petzolt screams to a young woman wearing a Confederate kepi to "get off my hill.",150 First and similar to the Living Historians of Figure 2.4, Sgt. Petzolt personifies a specific, white participant of the War. Moreover, Sgt. Petzolt's character serves to stand "in uniform” as those

\footnotetext{
${ }^{148}$ Battle of Vista Reenactment: San Diego, California (April 23, 2015).

${ }^{149}$ Interview with "Living Historian" Sgt. Petzolt.

${ }^{150}$ Ibid. Sgt. Petzolt's recreation of a Union soldier is strictly limited to 1863 combat and military details.
} 
who are interested "either have a feeling for it or you don't - most do."151 Sgt. Petzolt's recreation of a Union soldier offers visitors a narrow glimpse of the Civil War, characterized by accurate attire but flawed historical memories. His recreation presents a narrow narrative of an 1863 Union soldier, reinforced by his email, sgt1863@comcast.net. ${ }^{152}$ The partial insight provided by Sgt. Petzolt's character is only further underscored by his responses to questions about the War when asked to step out of character. When asked what motivated him to invest time, money, and energy into reenacting, Sgt. Petzolt insisted, "Schools do not teach enough American History."153 Sgt. Petzolt concerns himself with educating future generations about the Civil War; however, his role inherently restricts the narrative in the way he communicates Civil War history. By definition, Sgt. Petzolt's character can only reveal insights into the combat and the accompanying experiences. Like Civil War reenactment groups, Sgt. Petzolt "voluntarily give(s) of...time, knowledge, and passion for this fascinating time in history," but his character is founded in physical confines and, exclusively, white depictions of the War. ${ }^{154}$ In addition to Sgt. Petzolt's concern for education in America, he stated the War was fought for "States Rights," and Reconstruction was significant because it tried "to keep the country together.",155 Unwittingly underscoring the failures of reenactments, Sgt. Petzolt imbues curious tourists with knowledge that falls short of representing the historical complexities of the War. Sgt. Petzolt depicts a restricted portrayal and, arguably, one that is reduced, twice over. He rationalizes the War through "States Rights," - a term to be discussed further in Chapter Three - but most Union soldiers would not have justified Northern efforts for a cause of "States Rights." 156 Instead, his

\footnotetext{
${ }^{151}$ Ibid.

152 Ibid.

${ }^{153}$ Ibid. Sgt. Petzolt, whose very name portrays a narrow narrative of the War, expresses concern with education, but that historical narrative is limited, as well. The irony is in his attempt to be accurate he is, in fact, not accurate.

${ }^{154}$ Civil War Reenactment Society website.

${ }^{155}$ Interview with "Living Historian" Sgt. Petzolt.

${ }^{156}$ McPherson, What They Fought For, 51.
} 
explanation of cause for War endorses the memory of the Lost Cause Myth by embracing a justification supported by most Confederate veterans after the War. Sgt. Petzolt's recreation of a Union soldier falls short of accounting for anything other than the intricacies of soldiering at the Battle of Gettysburg, 1863.

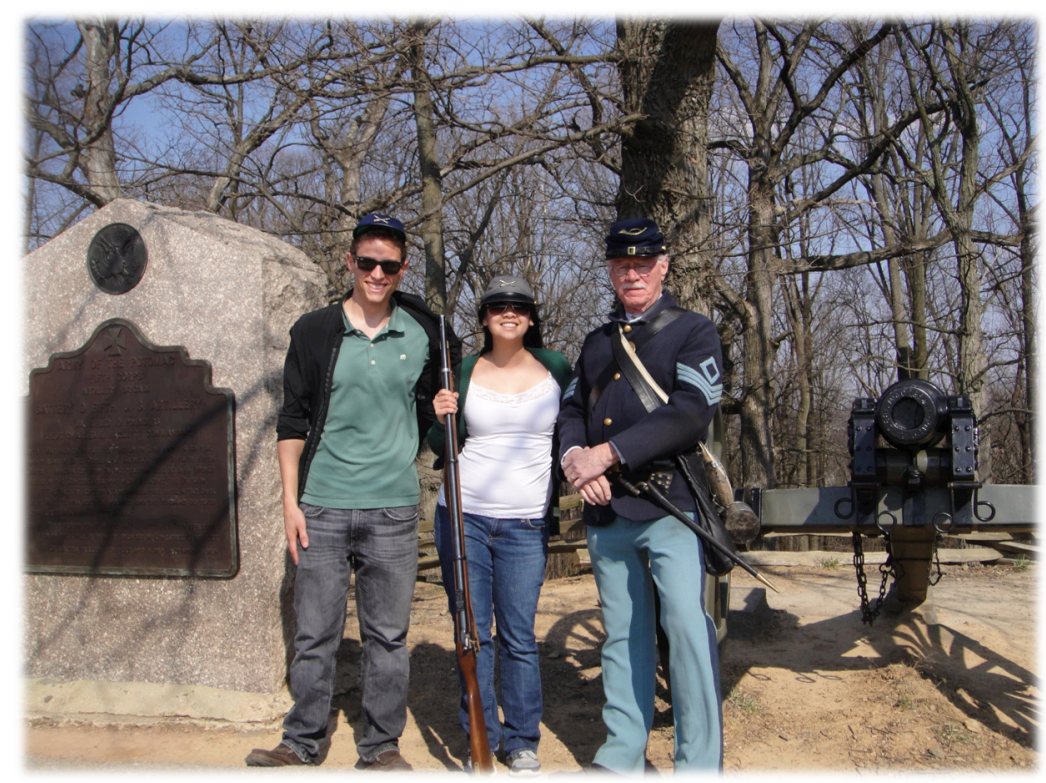

FIGURE 2.5: Tourists Austin English and Emily Phan pose for a photo with Living Historian, Sgt. Petzolt. Located atop Little Round Top at the Battle of Gettysburg in Pennsylvania (Photo taken April 5, 2013). ${ }^{157}$

Sgt. Petzolt's passion, as defined by his, "feeling for it," might be rooted in a genuine interest for Civil War history, but his portrayal validates a history of the War that omits the roles of African Americans from the historical record and American memory. ${ }^{158}$ His desire to educate reflects similar shortcomings by which modern reenactments fall short of representing an inclusive narrative of the War. For example, the American Civil War Society (ACWS) admits the "war is probably the most complex and socially controversial event in our country's history." ${ }^{159}$ However, the ACWS stops short of addressing these unnoted complexities and

\footnotetext{
${ }^{157}$ Interview with "Living Historian” Sgt. Petzolt.

158 Ibid.

${ }^{159}$ American Civil War Society, Inc. About ACWS (2001-2004). URL: http://acws.net/about_acws.htm
} 
assures, "There was no foreign powers attacking our country, thus causing a single united front of concern. The issue was clearly State Rights and what was the meaning of our forefathers' Declaration of Independence to hold for future generations if secession was not allowed."160 Figure 2.6 portrays a CWRS Confederate reenactor educating young children, highlighting infantry formations and the proper handling of firearms. Aside from the failure to address the admitted complexities of the War, the ACWS's modern reenactments embrace the same Reconciliation Memory and Lost Cause Myth that hindered earlier generations of Americans from understanding the War through the critical social and racial implications that defined the War. The ACWS might acknowledge and advertise a desire for a "diversified perspective," but a restricted timeframe singularly defines the War by the years it was waged and, consequently, the white men who fought it. Furthermore, an overview of infantry skirmishes teaches audiences about the experiences of combat, but that is the extent to which the public is educated about the War. The children of Figure 2.6 are not being taught about the elements of slavery that lead to war, the abolitionist movement, or the obstacles African Americans faced after the War.

${ }^{160}$ Ibid. 


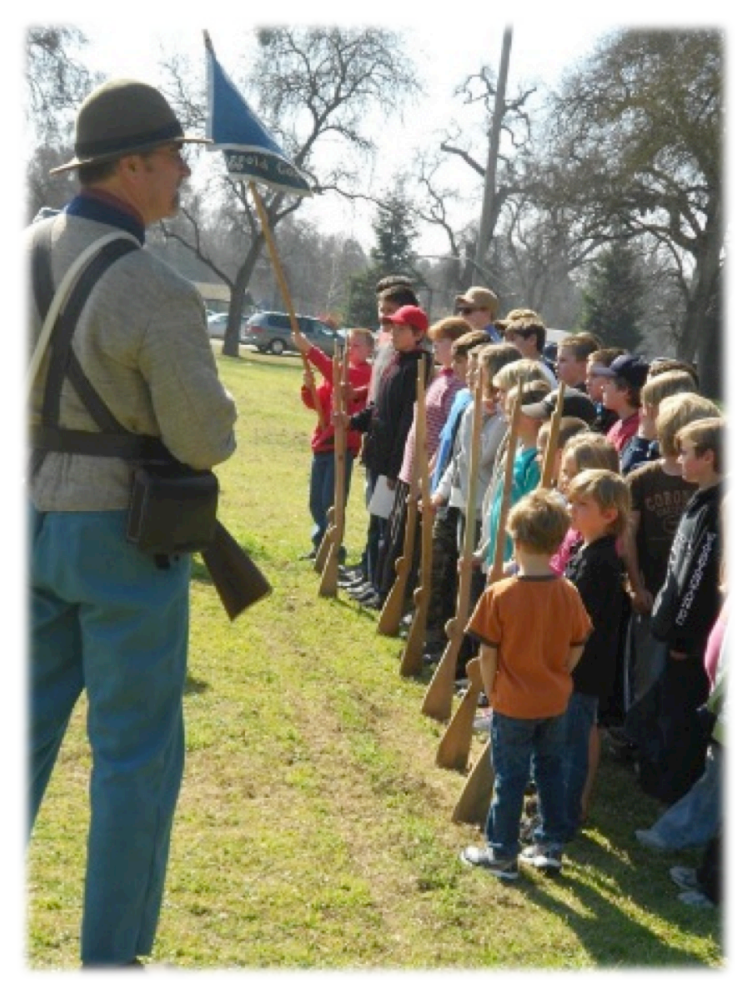

FIGURE 2.6: The Civil War Reenactment Society educates a younger generations of Americans through a narrow perspective - sensationalizing combat, excessive detail, and the experiences of soldiers (Civil War Reenactment Society; refer to footnotes for URL). ${ }^{161}$

Presently in 2016 America, modern reenactments regularly exclude racial issues that are pertinent to understand the War fully, continuing a legacy of earlier, white veterans who consciously celebrated their roles in American memory and history. Reenactment societies define the War as a "complex and socially controversial" time in American history," yet makes no mention of what these controversies are. ${ }^{162}$ This representation of history misleads the public and does not convey the significance of slavery as a cause of the War and other experiences of freed African Americans after 1865. Playing the role of Civil War soldiers, reenactors further rationalize the shortsighted depictions of history exemplified at modern reenactments.

\footnotetext{
${ }^{161}$ Civil War Reenactment Society, Photo Gallery, http://www.cwrs.info/Civil_War_Reenactment_Society/Photos.html\#53.

${ }^{162}$ American Civil War Society, Inc.
} 
Figure 2.7 depicts two photographs of modern Confederate reenactors while the Battle of Vista commenced in Southern California in March of 2011. The first, entitled "Confederate Selfie," shows a Confederate musician taking a photograph with his phone of both himself and the ensuing battle as Union and Confederate reenactors feign death. The second image of Figure 2.7, entitled "Dandy Confederates," shows a male Confederate couple posing with a picnic basket along the sides of the Vista battlefield. Both images demonstrate a sustained presence of a Reconciliation Memory at modern reenactments by highlighting the roles of white men who fought the War.
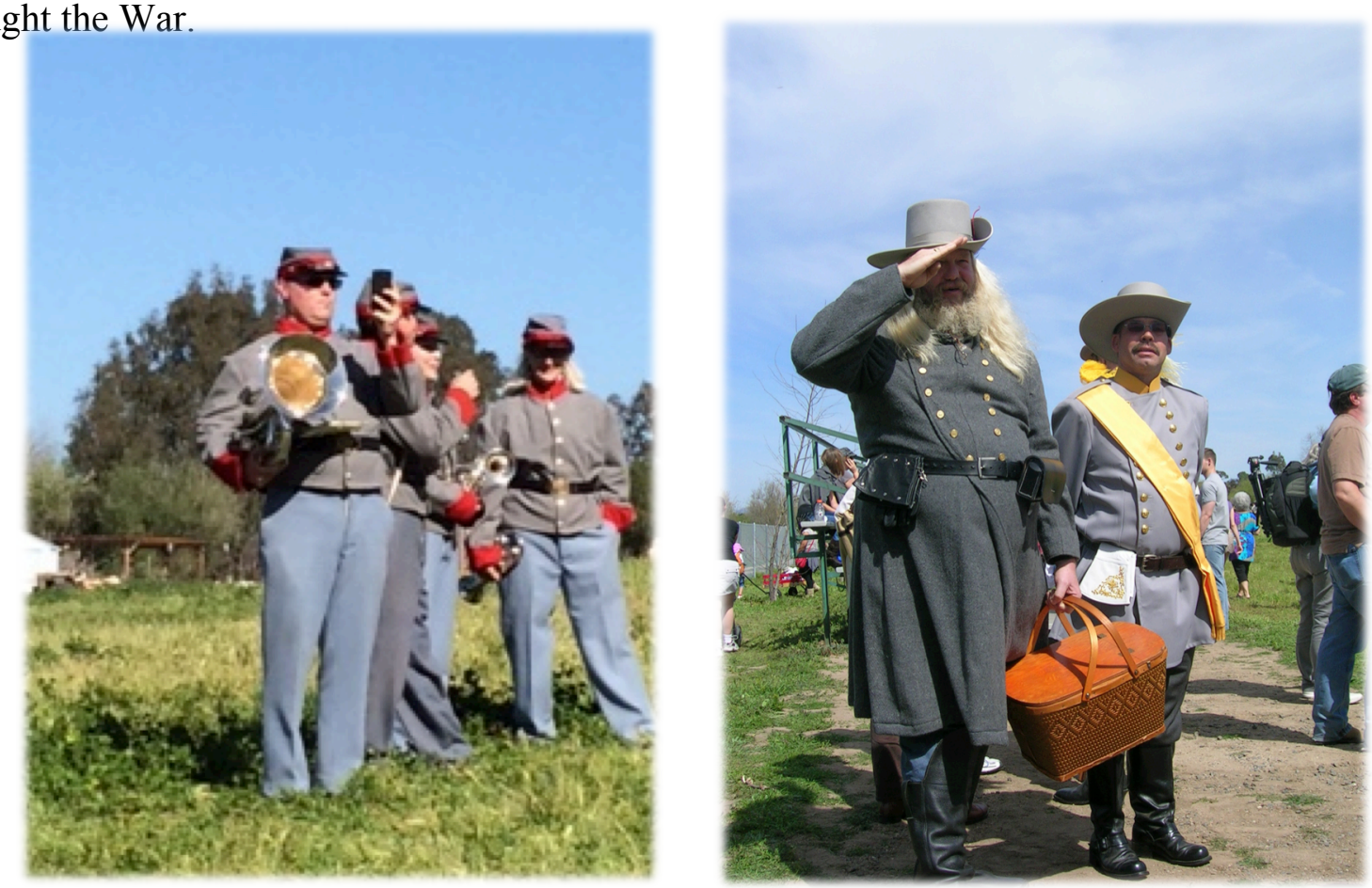

FIGURE 2.7: Entitled "Confederate Selfie" and "Dandy Confederates," these photographs depict Confederate reenactors at the Battle of Vista in Southern California. The Confederate musician takes a picture of himself and a Confederate couple enjoys a picnic as the battle ensues (Photos taken by Austin English on March 17, 2011). ${ }^{163}$

For these casual reenactors, reenactments offer a nineteenth-century camping experience in the twenty-first century - or for the "Confederate Selfie," an opportunity to play music, take photos, and be outdoors. However, as a casual camping experience, reenactments further

\footnotetext{
${ }^{163}$ Battle of Vista Reenactment: San Diego, California (March 17, 2011).
} 
sanitize the history of the War and de-emphasize issues of race. Similarly, the "Dandy Confederates" wear elaborate uniforms, but abstain entirely from the battle. Rather than participate in the fight, the couple attends the reenactment to enjoy a casual picnic while outfitted in Confederate garb. As both participants and spectators of the battle, the "Dandy Confederates" embrace their own casual representations of the Confederacy. Their "Confederacy" is one defined by Southern, well-dressed officers enjoying the company of other white men. Their presence suggests modern reenactments casually support a flawed perspective of the War by normalizing and highlighting narratives that, naturally, omit any conversation regarding race. The "Dandy Confederates," both literally and figuratively, withdraw from the battle and the essential conversations that, historically, Americans left unaddressed at War's end.

Modern, twenty-first century reenactments - physically, historically, culturally, and in American memory - continue to preserve a partial portrayal of the American Civil War as seen through masculine, white perspectives. A visual analysis of reenactments supports the presence of these shortcomings. Moreover, modern reenactments overlook critical issues of race that are crucial to the history of the War and important to understanding the implications for Americans of all genders and ethnicities. Reenactments, originating out of limited memories and perpetuating narrow perspectives for modern audiences, merit further analysis with regard to the vital racial narratives omitted to support a narrative dominated by white men. As reenactments organize “without partiality to any side," spectators must consider: didn’t the North win? ${ }^{164}$ Reenactments forsake partiality when exclusively highlighting white wartime experiences. After 1865 and into the twentieth century, new generations of freed African Americans confronted a hostile American society unwilling to consider the social shortcomings and injustices the post-

\footnotetext{
${ }^{164}$ Nevada Civil War Volunteers, “About the Nevada Civil War Volunteers” (Bulletins From the Front: January 19, 2016).
} 
War years left unaddressed. Modern reenactments sanitize Civil War history and sustain this omission of African Americans from the narrative for audiences in 2016 America.

In history, memory, and through the support of visual analysis, reenactments uphold a perception of the War dominated by white men. David Blight suggests the creation of "collective memories are the source of group-self definition, but they are never solely the result of unthinking decisions." ${ }^{" 165}$ In fact, the memories and legacies, by which modern reenactments are founded, were intentionally conveyed in hopes of sustaining a memory that, "armed those determined to control, if not destroy, the rise of black people in the social order."166 Those white Americans defended their social order, as a result of growing racial anxieties that arise after the War with the introduction of 4 million newly freed slaves. Similarly, twenty-first century white reenactors codify a nineteenth century social order of white masculinity for modern American audiences and without concerning themselves with the racial implications of the War. But why do modern American, white men feel obligated, consciously or subconsciously, to sustain a onehundred and fifty year old social order? A deeper discussion of Southern ideology, white masculinity, racial anxiety, and Dr. Jennifer Eberhardt's black crime association is needed to assess twenty-first century reenactments. Further analysis answers how and why modern, white American men preserve their control in an ethnically diversifying modern America through reenactments.

\footnotetext{
${ }^{165}$ Blight, Race and Reunion, 390.

${ }^{166}$ Ibid., 266.
} 


\section{CHAPTER THREE: \\ THE CIVIL WAR AND \\ THE VICTORY OF THE SOUTH}

The capacity to live in the past by memory also emancipates the individual from the tyranny of the present. He can choose, if he wants, to reverse a present trend of history in favor of some previous trend. He can, if he wishes, seek asylum from present tumults in a past period of

history, or use the memory of a past innocence to project a future of higher virtue. ${ }^{167}$

\section{- Reinhold Niebuhr}

(1949)

Although in 1865 the federal government defeated the Confederacy, ended slavery, and had set the machinery in motion that would result in the full emancipation of black slaves - it would take 100 years to accomplish Lincoln's "new birth of freedom."168 Modern white reenactors refight the American Civil War to celebrate Southern attitudes that the Union sought to destroy in the 1860s. Christopher Bates' research confirms that white men make up the majority of reenactment participants. These white men care nothing about commemorating the fight to end slavery, but now don uniforms and engage in mock battles to honor, and become like, the rebellious white men from 150 years ago who defied the Union. If nineteenth century, Southern attitudes persist in modern America, the South, not the North, won the Civil War in many respects. This paradox - white men in modern times admire other white men who were essentially traitors and threatened to destroy the nation - is an insight that cannot be ignored.

Twenty-first century modern reenactments are often "described by participants as tributes to the common soldier and the women allied with him," according to Brown. ${ }^{169}$ This description is indicative of a Southern white identity that modern reenactors reinvent when donning Civil War uniforms. ${ }^{170}$ As cited in Blight's Race and Reunion, white identity will be referred to as

\footnotetext{
${ }^{167}$ Blight, Race and Reunion, 255.

${ }^{168}$ President Abraham Lincoln's Gettysburg Address in 1863.

${ }^{169}$ Brown, Civil War Commemoration, 50.

${ }^{170}$ Barney, Making of a Confederate, 13.
} 
Southern ideology, which is exemplified in the narrowing, defining features of reenactments - an emphasis on combat, a history based in inadequate memories, and an absence of racial discussions. Before and after the War, Southern ideology focused on, "securing the supremacy of the white man...and the traditional liberties of the country." ${ }^{171}$ The placement of faulty memories and legacies in American culture, like the Lost Cause, allowed Southern ideology to justify the white authority enjoyed prior to the War. Southern white men secured, "white supremacy," in memory and culture, "as both means and ends," also securing "the place of women in its development." ${ }^{172}$ Modern reenactments maintain this nineteenth-century white masculinity and Southern ideology in response to modern social and racial anxieties - just as post-War Southerners consciously altered the War narrative to uphold their control of American society. As stated in the Introduction, Bederman classifies "manliness" and "masculinity" as essential elements used to sustain racial and social control in America. ${ }^{173}$ This racial and social authority is a product of a narrow, masculine, Southern ideology that underscores a white masculinity over any other aspect of the War. So, modern reenactments allow white reenactors to live as the authoritative, white, slave-owners that controlled their families and the direction of the country. ${ }^{174}$ Even for the reenactors who are not Confederate or slave-owners in character, modern reenactments embrace an underlying Southern ideology and white masculinity through recreations founded in male supremacy. Malcolm X reminded America on April 12, 1964 in Detroit that, "if you are South of the Canadian border, you're South." 175 Further discussion is

\footnotetext{
${ }^{171}$ Blight, Race and Reunion, 260.

172 Ibid., 259.

${ }^{173}$ Arnaldo Testi, review of Manliness and Civilization, by Gail Bederman. Journal of American History, Vol. 82, No. 4 (1996): 1590. Gail Bederman, Manliness and Civilization: A Cultural History of Gender and Race in the United States, 1880-1917 (Chicago and London: The University of Chicago Press, 1995) 307.

${ }^{174}$ Barney, Making of a Confederate, 22.

${ }^{175}$ Malcolm X, "The Ballot or the Bullet," Speech delivered 12 April, 1964 in Detroit (USA), https://www.cis.aueb.gr/Besides\%20Security/TALKS/TALKS-10X\%20(The\%20Ballot\%20or\%20the\%20Bullet).pdf.
} 
required regarding the correlations between Southern ideology and social anxieties that combine in the minds of some modern white Americans.

Confronting the anxieties of Southern whites intrinsically, "confronts the ambiguities and complexities of a South that has been effaced in the haze of the Lost Cause mythology."176 As the Confederacy demonstrated in 1865, elite, middle-class, and poor whites were united in an identity founded on their social supremacy over slaves. The South might have had its own social hierarchy, but it was where - elite or lowly - all whites could claim superiority over slaves. With this social stigma, their place in American society would go unchallenged and guarantee authority over enslaved African Americans. Furthermore, the War left women and children at home, forcing Southern men to abandon their power over the household. The independence that women and children obtain as men go to war only deepen social anxieties and stirs the racial anxieties of white men. Malcolm X preached that "Southern white identity was a product of defeat," and a direct response to anxious, white men who saw an end of to their ways of life. ${ }^{177}$ Southern “white men's loss of power over their own children and wives accompanied by a loss of leverage in public life," inspired white-masculine portrayals of the War that eliminated racial issues from national dialogue. ${ }^{178}$ Southern ideology omits the racial overtones of the War and, "by removing it (race) from serious discussion, he (the white male)...naturalize(d) hierarchy."179

Similarly, modern reenactment battles and camps, like the one depicted in Figure 3.1, embody this Southern ideology, promoting the dominance of white men in society for modern American audiences. White men maintain their supremacy at modern reenactments, while women support white dominance by playing the roles of passive, domestic, and supportive ladies

\footnotetext{
176 Ibid. 13.

177 Ibid.

${ }^{178}$ Maclean, Behind the Mask, 41.

${ }^{179}$ Ibid., 131.
} 
of nineteenth century Southern ideology. Cheri Gainor, a reenactor from Frederick, Maryland, portrays a camp laundress and insists that reenactments have "impact on" her life. ${ }^{180}$ Although enthusiastic, passionate, and open-minded to discussing the Civil War - a variety of her responses enlighten and reveal the white masculinity that dominates reenactments and camps. Gainor suggests she enjoys, "listening to the gents discussing and debating the issues of those times. War stories of key people in battle, battle tactics, what should the south have done differently. To me this is when my history lessons begin.” Moreover and beyond Gainor's "listening," to the white men of reenactment camps, she reveals, "as the old saying goes, best to be seen and not heard as most southern women do." ${ }^{181}$ Correspondingly, Drew Gilpin Faust describes early white, male attitudes towards women and suggests, "women were regarded in mid-nineteenth-century America as apolitical in there very essence; their aggressions and transgressions could be - and largely had been - ignored during the war." ${ }^{\text {"182 }}$ When reenacting a camp laundress, Gainor becomes part of a nineteenth-century Southern ideology in modern America - she is seen and not heard. Her participation is ultimately ironic because she and other women participate in an exercise that seeks to exclude them. As with all reenactors, Gainor wants to "become part of history," but falls short of asking what critical issues come out of that history. When asked about race and reconstruction she answered: "Since I am only in 1863, reconstruction has not begun." ${ }^{\text {183 }}$ Modern reenactments normalize nineteenth-century white masculinity in modern America with the mask of traditional behavior for the recreated timeperiod. White, Southern attitudes of the nineteenth century - marked by white, social authority gain expression through the white men that make up the majority of modern reenactors.

\footnotetext{
${ }^{180}$ Cheri Gainor, Interview with Union laundress from Gettysburg Battlefield, Pennsylvania, July 30, 2013.

${ }^{181}$ Interview with Union Laundress, Cheri Gainor.

${ }^{182}$ Faust, This Republic of Suffering, 242.

${ }^{183}$ Interview with Union Laundress, Cheri Gainor.
} 
Nineteenth-century white men expressed their masculinity in America, something that modern white men feel they cannot do unless they reenact soldiers. On a reenacted battlefield, white men with guns can experience victories they cannot enjoy in their modern, real lives.

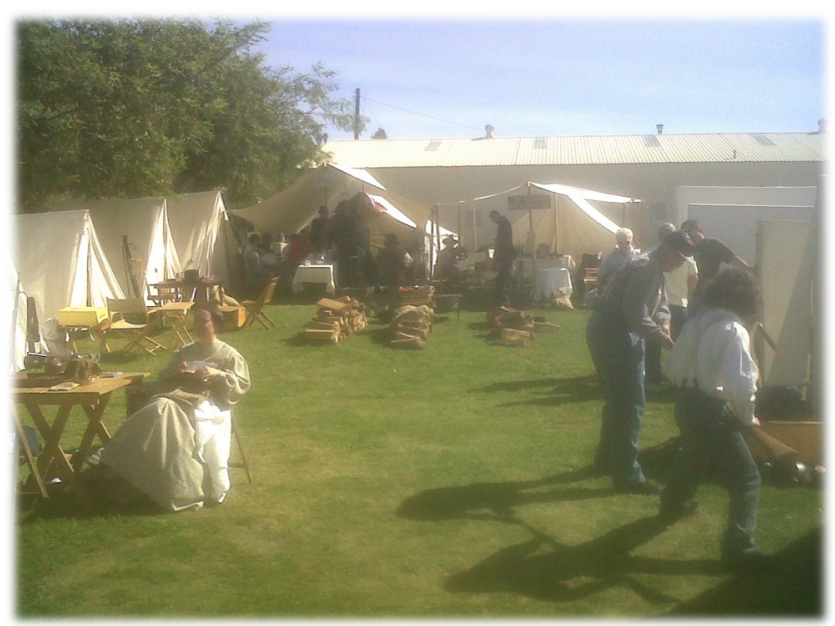

FIGURE 3.1: Battle of Vista in San Diego, California incorporates a variety of camps. After the battle concludes, reenactors reunite. Reenactments recreate and sustain a nineteenth century Southern ideological atmosphere where modern white men can reinforce their own control in America in 2016 (Photograph by Austin English on April 23, 2015). ${ }^{184}$

Equally misrepresented in modern, twenty-first century reenactments, African-American reenactors occasionally participate. While reenactments might defend this shortcoming as historically accurate in terms of white to black troop proportions (African Americans combat units reached about ten percent of the Union Army total by War's end), this explanation reduces the ensuing exclusion of an Africa-American narrative to a mere detail. In modern reenactments, as seen in Figure 3.2, the representation of African Americans is misrepresented and, as with female participants, serves to highlight their exclusion from a simulated nineteenth century. Reenactments undervalue African American wartime contributions and experiences. African Americans accounted for approximately 180,000 Union soldiers and, similarly, the Confederacy was able to sustain itself because of the use of a large slave labor force. Although the Union would likely have won without African-American soldiers, black soldiers began to see combat

\footnotetext{
${ }^{184}$ Battle of Vista Reenactment: San Diego, California (April 23, 2015).
} 
more often by the end of the War. ${ }^{185}$ However, the depiction in Figure 3.2 is neither historically accurate, nor dignifying, as the Union African-American reenactor is singled out amongst white reenactors. In the context of the reenactment, an African American soldier would have been subject to rampant racism in 1863. African Americans, especially in the Union Army, consciously fought to bolster their claim for equal rights. ${ }^{186}$ Enduring widespread racism in the Army, "black troops suffered from intense discrimination," in hopes of an enfranchised future. ${ }^{187}$ Just like female reenactors, African-Americans participate in reenactments that ultimately aim to exclude them through Southern attitudes that are bolstered in the process. Consequently, reenactments set aside racist attitudes.

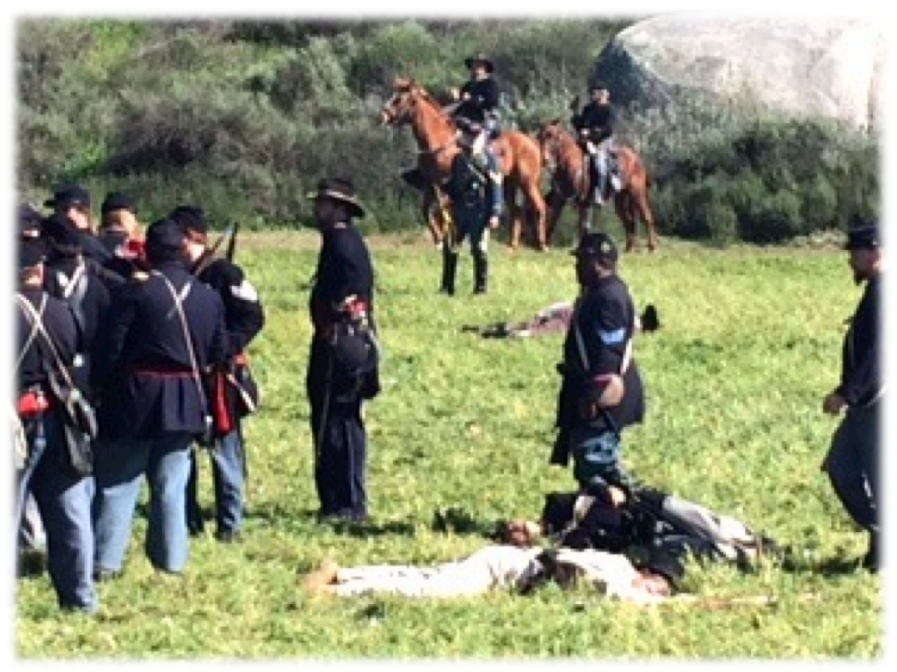

FIGURE 3.2: At the Battle of Vista reenactment in Southern California, an African-American reenactor stands alone (Photograph by Austin English on April 23, 2015). ${ }^{188}$

If modern reenactments sustain white masculinity, what inspires twenty-first century white men to reenact and why, consciously or subconsciously, would white American men be anxious? Particularly in the nineteenth century, Southern white males fought to maintain control over the slave society they had grown accustomed to since the founding of America.

\footnotetext{
185 Jones, America Civil War, 225 and 234.

${ }^{186}$ Ibid., 234.

${ }^{187}$ Ibid., 221.

${ }^{188}$ Battle of Vista Reenactment: San Diego, California (April 23, 2015).
} 
Southern ideology, defined by white male control over both African Americans and the family unit, remained predominant in American society well into the twentieth century. James Baldwin in 1957 witnessed these anxieties of white America as he "saw the South's unspoken (by whites) sexual past in the colors of all the faces of black people." ${ }^{189}$ Noting the history of unaddressed social and racial issues during Southern segregation in America, Baldwin recognized the hidden anxieties and hypocrisy that white American men faced in everyday, post-Civil War America.

Additionally, Anthony Rotundo explores the development of manhood in American culture. He determines that masculinity, "was not completely transformed at the turn of the (twentieth) century," and that Americans continued to respect a masculinity and, "selfexpression," characterized by, "competition, boldness, ambition."190 These attributes do not describe typical nineteenth century masculinity, but the variance indicates modern men can exhibit "self-expression" through reenactments. If a modern American society pressures males to be successful and ambitious, modern reenactments provide white men a, "retreat from and return to the ordinary world," where anxieties are uninhibited and, "bankers, professors, factory workers, and postal clerks all transcend their regular stations in life and prepare for heroic battle against the enemies of society." ${ }^{191}$ Moreover, Rotundo identified modern anxieties, some defined by a, "growing distance between fathers and sons in the modern world." As a means to maintain authority, white reenactors confront these modern anxieties by projecting dominance and reaffirming a nineteenth-century family unit through modern reenactments. Evidence of this projected dominance as a means of alleviating anxiety appears at modern reenactments. Figure 3.3 depicts a poster at the Battle of Vista reenactment in Southern California. Other than the lack

\footnotetext{
${ }^{189}$ Blight, American Oracle, 218 and, for reference, Rotundo, American Manhood, 282. Rotundo explains selfexpression and recreational activities: "They managed to build social support for their own self-expression, even as they blocked outlets and acceptance for some of the same impulses in women."

${ }_{190}$ Rotundo, American Manhood, 282-283.

${ }^{191}$ Gibson, Warrior Dreams, 9/308.
} 
of historical content demonstrated through reenactments as "tax deductible," Figure 3.3 is significant because it notes that reenactments are a " $20^{\text {th }}$ century stress release." But what anxieties do white Americans experience?

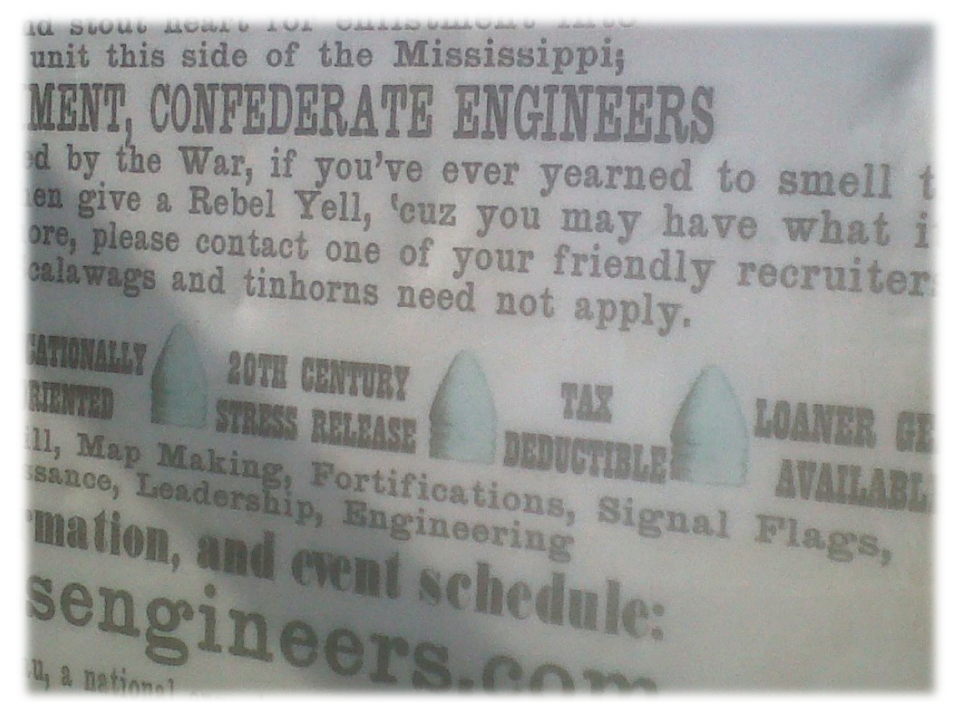

Figure 3.3: Many of the units at reenactments advertise and encourage spectators to join. This poster not only highlights the overemphasis placed on the details of "fortifications" and "signal flags," but the need for white reenactors to release "stress" in modern America. (Photograph by Austin English on October 26, 2011) ${ }^{192}$

Dr. Jennifer Eberhardt's research identifies implicit racial anxieties in American white men and explains their need to preserve nineteenth-century masculinity in modern America through reenactments. The experiments organized and administered by Dr. Eberhardt tested white males' reactions to photographs of both black and white Americans immediately after being shown the image of a weapon. Eberhardt's results decisively conclude that white men exposed, "to the black faces beforehand, were able to identify the crime relevant objects quicker. Exposer to the white faces led them to need more frames." ${ }^{, 193}$ Although Eberhardt's experiments are intended to help police officers identify implicit biases, the evidence of an implicit bias in

\footnotetext{
${ }^{192}$ Battle of Vista Reenactment: San Diego, California (October 26, 2011).

${ }^{193}$ Claudia Dreifus, Perceptions of Race at a Glance, A MacArthur Grant Winner Tries to Unearth Biases to Aid Criminal Justice, NewYorkTimes.com, (January 5, 2015).
} 
American society supports the claim that modern reenactments sustain nineteenth-century masculinity as a result of modern racial anxieties.

According to Eberhardt, the presence of implicit biases represents a larger "metaphor for race relations. Not being able to read another person's face - it symbolizes a psychological distance that makes it difficult to understand the experiences of another group."194 Similarly, modern reenactments sensationalize a white, nineteenth century, masculine history of the War that omits critical racial issues as a result of these social biases and anxieties. Associating blacks with crime is unlike stereotypical racism and does not suggest that all white men should be condemned for their implicit biases. ${ }^{195}$ Rather, the identification of this racial, criminal anxiety in American society can be used constructively to identify shortcomings in American society and, "help people become aware of the subconscious ways race operates."196 Additionally, according to the 2013 FBI Uniform Crime Report, "90 percent of black victims were killed by black offenders."197 These statistics suggest that African Americans usually commit crimes against other African Americans, exposing the irrationality of white fears. Eberhardt suggests most Americans believe racism is no longer a modern issue, but the General Social Survey (1983) and Public Opinion Poll Survey (2004) report: only seventeen percent of white Americans report social issues as racial concerns, only seven percent think race is a social worry, and only six percent report contemplating racial issues. ${ }^{198}$ Twenty-first century African Americans are still subject to white anxieties and implicit biases that, "dehumanize" them still

\footnotetext{
${ }^{194}$ Ibid., and Eberhardt, "How Racial Residue..." Lecture.

${ }^{195}$ Dreifus, Perceptions of Race, NYtimes.com.

${ }^{196}$ Ibid.

${ }^{197}$ Michelle Ye Hee Lee, "Fact Checker: Giuliani's claim that 93 percent of black murder victims are killed by other blacks" TheWashingtonPost.com, (November 25, 2014).

${ }^{198}$ Dreifus, Perceptions of Race, General Social Survey (1983) and Public Opinion Poll Survey (2004) as referenced by Jennifer Eberhardt.
} 
reside in white American perceptions of African Americans. ${ }^{199}$ In response to these anxieties, Rotundo suggests people create, "new metaphors that take us beyond separate spheres and contending passions."

Reenactors recreate and preserve a socially dominating conception of masculinity that reaffirms their own control in response to a growingly diverse American population. This Thesis posits that modern anxieties encourage white American men to reenact the Civil War to sustain a masculinity based on Southern ideologies. Moreover, areas of American public life reflect the anxieties and controversies that modern reenactments seek to amend through a glorification of nineteenth century masculine principles. Through the preservation of nineteenth-century Southern ideologies, white reenactors challenge anxieties that remain key features of a modern American South.

Norman Mailer, an American novelist and journalist, noted enormous damage the terrorist events of 9/11 "brought to America's morale.",201 He suggests that President Bush pressed for war in the Middle East to achieve a "psychic rejuvenation" or boost in public morale. Mailer observes that, "the good average white American male had had very little to nourish his morale...unless he happened to be a member of the armed forces." ${ }^{202}$ Surpassed by women in society and overcome by minorities in sports, modern white men maintain dominance in society through, "connections with the military." Mailer reveals the "sanitized but terrific" military roles bolstered by wartime that modern white men use to reclaim their place in society, even if it is experienced through the TV. ${ }^{203}$ Similar to the "sanitized but terrific" war news reported on TV

\footnotetext{
199 Ibid.

${ }^{200}$ Rotundo, American Manhood, 293.

${ }^{201}$ Norman Mailer, “The White Man Unburdened,” Digital Copy - The New York Review of Books (July 17, 2003). http://www.nybooks.com/articles/2003/07/17/the-white-man-unburdened/.

202 Ibid.

${ }^{203}$ Ibid.
} 
to American white men, modern Civil War reenactments give white men the opportunity to project their relevance in a world that no longer acknowledges them as necessary to social order. Further discussion regarding American anxieties reveals a modern America founded in Southern attitudes that continue to stir social controversy.

A number of additional sources suggest that Southern ideology and attitudes survived to present time and inspire new generations of Americans. Referencing the racism and social strife African Americans faced in the 1960s throughout the country, Malcolm X suggested the American South was anything south of Canada and that, "up here, in the North you have the same thing." ${ }^{, 204}$ Although the Civil Rights Movement ensured future political enfranchisement for African Americans, the pervasive Southern ideology referred to by Malcolm X remains a characteristic of many American regions, even in northern parts. For example, the journalist Steve Kornacki says many regions of the South express "racial sensitivities," and politicians, historically, have appealed to Southern populations by 'using the term 'state's rights' - the rallying cry for every politician who'd fought civil rights legislation in the 1950s and 1960s.",205 Additionally, journalist George Packer refers to the "Southernization of American Life," as a "turn away from centralized liberalism," and describes an America inspired by Southern ideology that "elected (a U.S. President) between 1976 and 2004... by birth or by choice, a Southerner, except Ronald Regan, who enjoyed a sort of honorary status."206 However, the South is "becoming isolated again," because every, "demographic and political trend that helped reelect Barack Obama runs counter to the region's self-definition: the emergence of a younger, more diverse, more secular electorate, with a libertarian bias on social issues and

\footnotetext{
${ }^{204}$ Malcolm X, "The Ballot or the Bullet” April, 1964.

${ }^{205}$ Steve Kornacki, “The 'Southern Strategy,' Fulfilled” (Salon.com, Thursday February 3, 2011), http://www.salon.com/2011/02/03/reagan_southern_strategy/.

${ }^{206}$ George Packer, "Southern Discomfort” (NewYorker.com, January 21, 2013), http://www.newyorker.com/magazine/2013/01/21/southern-discomfort-4.
} 
immigrations. ${ }^{" 207}$ Packer concludes that the Southern ideology espoused by, "the Solid South speaks less and less for America and more and more for itself alone., ${ }^{208}$ White American men who identify with Southern ideology do not maintain the same control in American society that they had for centuries. Moreover, the historian Garry Wills highlights how the American South does not, "discriminate between the good and the evil of its past, or pretends that the latter does not linger into the present: Some in the South deny that the legacy of slavery exists at all in our time." ${ }^{209}$ As Malcolm X suggested that Southern ideology was rampant throughout America in his time, Southern attitudes continue to circulate in modern America with, "the worst aspects of the South...resurfacing under Obama's presidency.",210 Wills calls the South, "defeated and dumb," and his analysis reinforces Packer's evaluation that, "the South's vices - 'violence, intolerance, aversion and suspicion toward new ideas' - grow particularly acute during periods when it is marginalized or left behind," including modern times. ${ }^{211}$

Feeling increasingly marginalized in modern America, white Americans find themselves in a socially anxious context where they have decreasing influence. However, not all white men share the same fears, just as it is true that not all white men in the South possess the same racial anxieties. Civil War reenactments celebrate a southern perspective that finds favor with some men across the United States. In short, the ideology of white males in the South, by accident or design, speaks to, and erases, the anxieties experienced by white males elsewhere in the nation. According to Commonwealth Fund/CDC Wonder Database, a report by David Squires and David Blumenthal, modern middle-aged white males, “"on a range of social and economic

\footnotetext{
${ }^{207}$ Ibid.

${ }^{208}$ Ibid.

${ }^{209}$ Garry Wills, "Dumb America” (NYbooks.com/NYR Daily, January 21, 2013), http://www.nybooks.com/daily/2013/01/21/dumb-america/.

${ }^{210}$ Ibid.

${ }^{211}$ Packer, "Southern Discomfort" (2013).
} 
indicators... have been falling behind in the $21^{\text {st }}$ century.",212 Squires and Blumenthal report that, "between 1999 and 2014, mortality rates in the U.S. rose for white Americans aged 22 and 56." 213 The report goes on to conclude that the mortality gap for white men was so large that it accounted for an additional, "100 dead, middle-aged white people for every 100,000.,"214 Additionally, modern African Americans have a declining mortality rate, while "white Americans is increasing - a historically anomalous trend." ${ }^{215}$ Olga Khazan notes that this trend is strongly due to the fact that, "middle-aged white people," are, "drinking more, using more opioids, and killing themselves at higher rates."216 Statistically, white males in America are dying more and living in an America that is demographically diverse, but still Southern in ideology. Now in response to a changing America, some white men in modern times continue to reenact the Civil War in order to recreate a nineteenth century, male dominated atmosphere. Nineteenth-century white men openly expressed their masculinity in America, something that modern white men feel they cannot do unless they reenact soldiers. White, Southern attitudes of the nineteenth century - marked by white, social supremacy - persist through the white men that make up the majority of modern reenactors.

Few modern issues in America are as representative of racial controversy as debates over the Confederate battle flag (see Figure 3.4). ${ }^{217}$ In a 2016 America, gun laws and second amendment debates turn into passionate disputes over the presence of the Confederate battle flag of the Confederate States of America in public spheres of influence. Especially after Dylann Roof murdered eight members of Charleston's Emanuel African Methodist Episcopal Church

\footnotetext{
${ }^{212}$ Olga Khazan, "Why Are So Many Middle-Aged White Americans Dying?" (TheAtlantic.com, January 2016), http://www.theatlantic.com/health/archive/2016/01/middle-aged-white-americans-left-behind-and-dyingearly/433863/.

${ }^{213}$ Ibid.

${ }^{214}$ Ibid

${ }^{215}$ Ibid.

${ }^{216}$ Ibid.

${ }^{217}$ Jason Ward, “The Cause Was Never Lost,” The American Historian, History and Animals (November, 2015), 24. 
while in a prayer group, and was depicted in news reports to be, "fond of posing with banners of various white supremacist regimes - particularly the Confederate State of America," some Americans challenged the need for a Confederate flag in the twenty-first century. ${ }^{218}$ Those opposed to the flag seized the opportunity to highlight a Southern history of white supremacy where Southern defenders maintain the Confederate flag as a symbol of Southern heritage, not racial inequality. ${ }^{219}$ However, some Americans continue to view the flag with a racial past, as "it had always been since its creation - a banner for a white supremacist regime." 220 This opposition motivated the organization of Black Lives Matter activists to demand change and the removal of the Confederate flag from public spaces. First, the legacy of the Confederate flag exemplifies the nineteenth century racial inequalities Americans continue to contend with after the Civil War. As a result, the white masculine anxiety that follows the War is also embodied in modern reenactments as white Americans seek to maintain dominance. Second - and equally as significant - modern African Americans take an active role to engage the shortcomings of American society through movements like Black Lives Matter, truly honoring those who suffered before them at the hands of slavery by ridding America of symbols of hate for future generations. The emergence of groups like Black Lives Matter suggests modern African Americans are willing to look at racial issues left unresolved. Modern Confederate flag supporters often encounter organizations assembling to oppose support of the Confederate symbol. Figure 3.5 shows a photograph of an African American peacefully protesting those advocating the Confederate flag. His shirt depicts the phrase, "Turn your Back on Hate," further underscoring the ties between Civil War symbols, like the Confederate flag, and modern, white

\footnotetext{
${ }^{218}$ Ibid., 24, 25.

${ }^{219}$ Ibid.

${ }^{220}$ Ibid., 25.
} 
social and racial anxieties. ${ }^{221}$ These efforts indicate the presence of modern racial tensions in America that trace back to the Civil War. Edward Ayers best summarizes the importance of Civil War discussions in modern America: "history can sometimes be more controversial than current events. Public memory of the Civil War is not uniform. Its causes and effects are still being probed and debated." ${ }^{222}$ Ayers describes the fluidity and developing nature of American memory - especially in terms of the American Civil War as the Sesquicentennial concluded in 2015 and Americans continue to debate the War's significance.

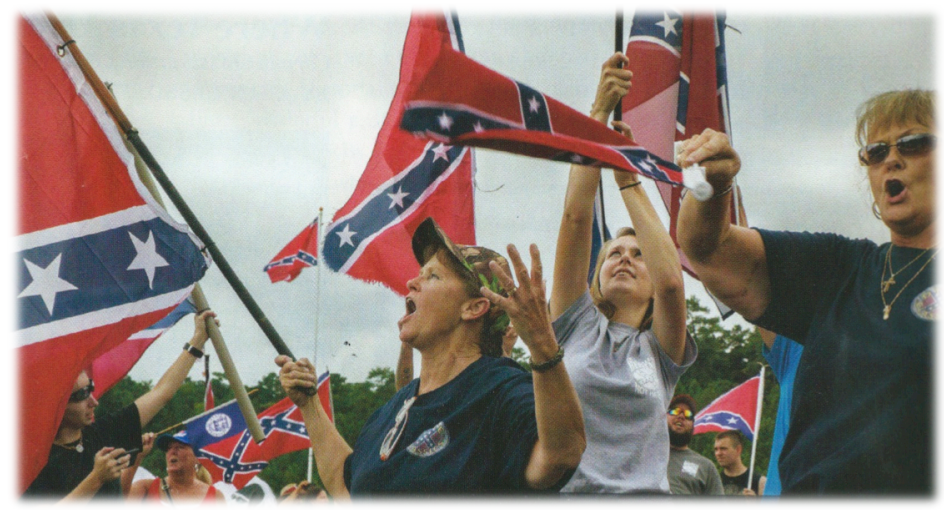

Figure 3.4: Confederate Flag Rally at Stone Mountain Park on August 1, 2015. Animated and passionate, supporters of the Confederate battle flag in public spaces protest claims that the flag holds an oppressive, white supremacist history in modern America (The American Historian, No. 6, November 6, 2015, photo by John Ramspott). ${ }^{223}$

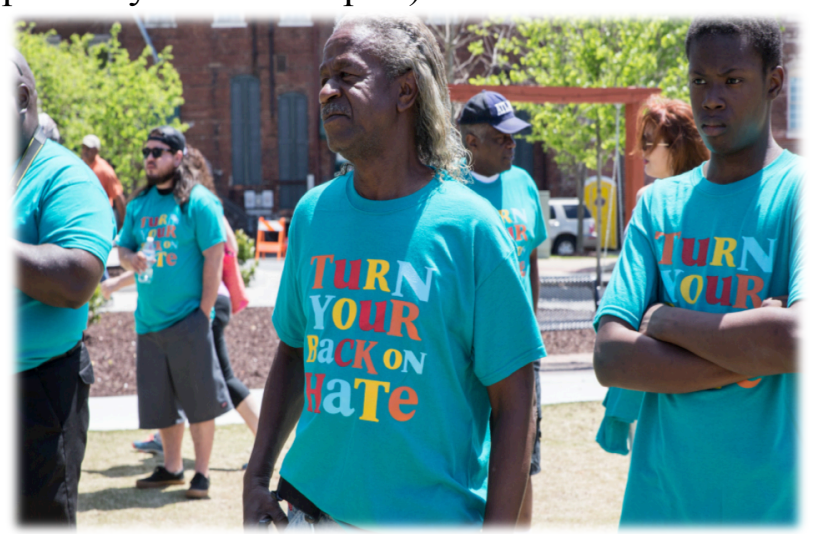

Figure 3.5: An African American gentlemen stands with other protesters of all races and backgrounds, calling for the end of symbols of the Confederacy, like the battle flag, in public spheres of influence. ${ }^{224}$

\footnotetext{
${ }^{221}$ Ramspott, photographs of the American South, August 1, 2015.

${ }^{222}$ Ayers, America's War, XIII.

${ }^{223}$ Ward, "The Cause Was Never Lost," 24, photographer John Ramspott.

${ }^{224}$ Ibid.
} 
Modern white masculinity and, correspondingly, social anxieties endure through extremists like Dylann Roof - even if marginal - who endorse Civil War narratives and symbols to uphold their own superiority. The photographs included under Figure 3.6 appeared from a collection from across the American South. ${ }^{225}$ Following photographs of a Flag Rally are the images of a Ku Klux Klan cross burning on April 23, 2016. The images speak volumes to the nineteenth century white, masculine, brotherhood upheld at the KKK events. The Ku Klux Klan, an organization founded in violence and organized to ensure the disenfranchisement of African Americans in the nineteenth century, continues to embrace the Southern ideology of a War lost over 150 years ago. Racially biased imagery, in conjunction with the burning of the insignia of Nazi Germany, suggests that the extremists of American society continue to preserve Southern ideology and white masculinity amongst modern racial threats.
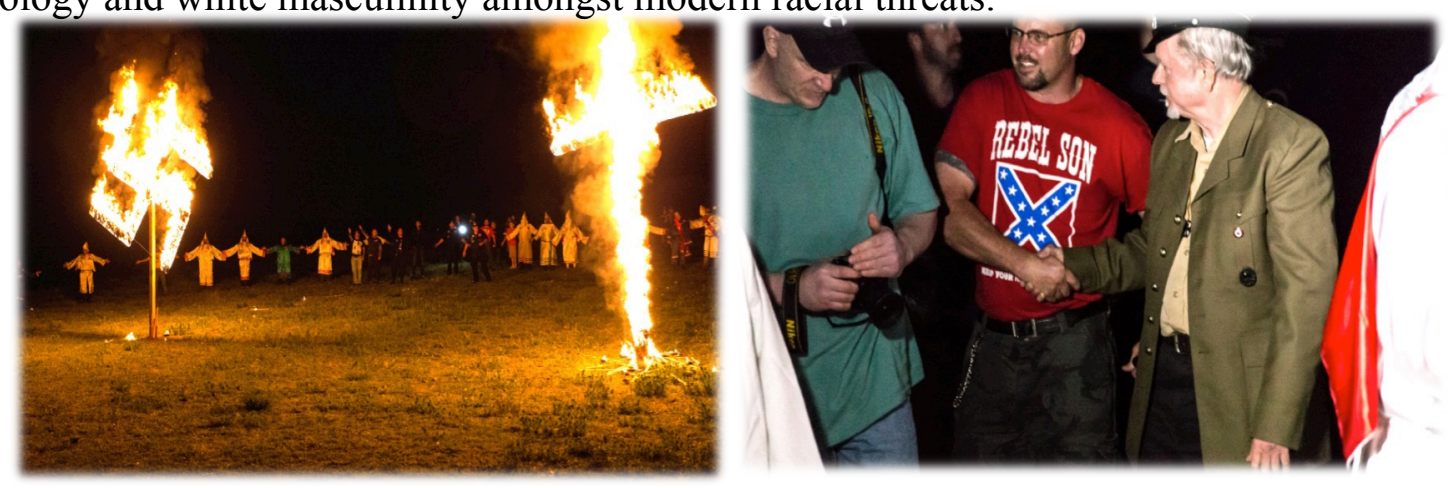

Figure 3.6: A Ku Klux Klan cross burning on April 23, 2016. A young KKK supporter, wearing a Confederate battle flag shirt, shakes the hand of an older man in neo-Nazi attire. The modern occurrence of KKK events indicates the racism and white masculinity of nineteenth century Southern ideology is alive and active in modern America. The Civil War ended in April of 1865 . Over 152 years later and white Americans rally to praise white superiority in America. (Photographs by John Ramspott on April 23, 2016, https://www.flickr.com/photos/jramspott). ${ }^{226}$

There are few images other than those presented in Figure 3.6 that represent a heightened white male anxiety and the desire to preserve and celebrate a prevailing brotherhood. KKK events represent the most extreme of vessels by which white American men enhance a

\footnotetext{
${ }^{225}$ John Ramspott, professional photographer chronicles his travels through the American South. Reference: https://www.flickr.com/photos/jramspott/20209219132/.

${ }^{226}$ Ramspott, photographs of the American South, April 23, 2016.
} 
white, masculine narrative of the War for twenty-first century audiences. The purpose of this examination is not to equate Civil War reenactors to KKK members. Rather, the significance rests in the Southern ideology and white masculinity that manifests itself in the implied racist values and white masculinity upheld at both - one being extreme and the other, reenactments, occurring consciously and subconsciously as result of embedded collective memories and anxieties in American culture. Similarly, but not necessarily consciously, modern Civil War reenactments omit racial issues. In this sense, modern reenactments literally give white reenactors, "asylum from present tumults in a past period of history, or use the memory of a past innocence to project a future of higher virtue."227

The images of Figure 3.6 indicate that modern social and racial anxieties persist and most Americans believe race is not "in a good place" in twenty-first century America. ${ }^{228}$ From national to local communities, topics grounded in the unresolved issues of the Civil War continue to be debated in American cities like San Diego - no where near where a Civil War battle never even came close to occurring near. The City of San Diego recently voted to change the name of Robert E. Lee Elementary to Pacific View Leadership Elementary; a divided public advocated "no justice" in the cause because "the majority of citizens opposed this name change. ${ }^{229}$ San Diegans vested in Lee Elementary may be precisely because of the deletion of racial consequences from Civil War memory. Modern Civil War reenactors celebrate traitors who threated to destroy the nation many of us revere in modern times. Moreover, they overlook race and prefer to emphasize brawny displays of manhood in order to reclaim their fleeting dominance in the modern world. With such deep-seated convictions on both sides of the debate

\footnotetext{
${ }^{227}$ Blight, Race and Reunion, 225

${ }^{228}$ Matthew Cooper, "Ken Burns's Merciful Portrayal of the South in 'The Civil War' is a Good Lesson for 2015" (Newsweek.com: September 11, 2015).

${ }^{229}$ Salvador Rivera, "School Board Renames Robert E. Lee Elementary" (Fox News: Fox5sandiego, May 24, 2016).
} 
over the meaning of the Civil War and relevant symbols, the future and sustainability of reenactments remains in question. 


\section{CONCLUSION: \\ THE FUTURE OF REENACTMENTS}

"A family's collective memory is strong, and in that memory the guns have not been long silent. In our imagination, the ashes of Civil War campfires are still warm, and Rebel Yells and Yankee huzzahs still echo in the hills. ${ }^{, 230}$

Many questions arise as modern American racial anxieties persist alongside reenactments. How do modern African Americans combat the narratives of the Civil War for modern audiences? Can reenacting marginalized blacks in American history be a useful tool to tackle the social and racial limitations of modern reenactments? According to Azie Dungey, the creator/star of Ask a Slave and shown in Figure 4.1, reenacting provides a unique opportunity for African Americans in modern America. She believes, "One of the greatest attractions of reenactments is that it offers the opportunity to give voice to formerly marginalized groups, and in recent years more and more living history sites have moved to incorporate slaves and servants into their rosters of interpreted characters. ${ }^{, 231}$ Perhaps, a solution to readdress modern Civil War reenactments includes depicting marginalized roles in thought-provoking, educational settings.

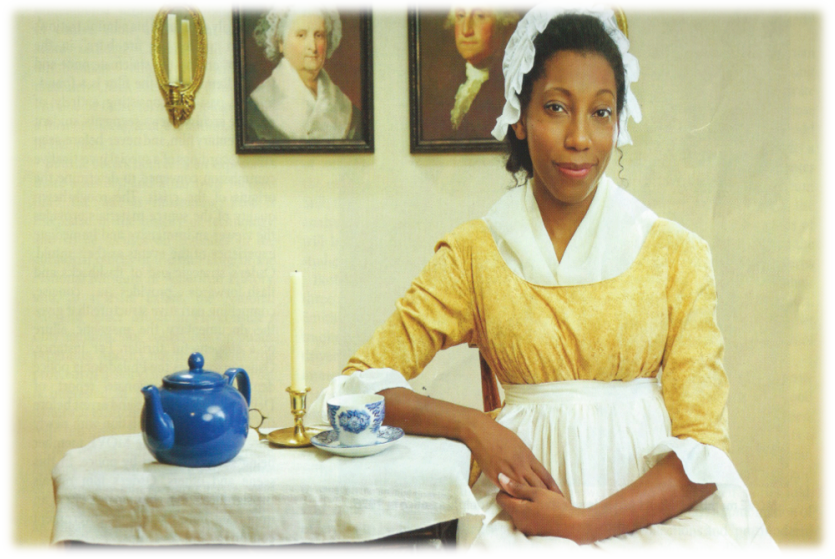

Figure 4.1: "Azie Dungey is the creator, writer, and star of the comedy web series Ask a Slave (askaslave.com), in which she plays, 'Lizzie Mae,' a domestic-service slave at Mount Vernon...Dungey based the show on her real-life experience as a historical interpreter at the Mount Vernon historic site." (Photo by Johnny Shryock, The American Historian, No.1, August 2014.). ${ }^{232}$

\footnotetext{
${ }^{230}$ Jones, American Civil War, 682.

${ }^{231}$ Melish. "[Re]Living Slavery" 37.

${ }^{232}$ Ibid., 39.
} 
Up until this point in this examination, one topic has been left unaddressed: African American women in Civil War reenactments. In recent year, national sites and monuments have utilized portrayals of African American women as slaves or servants. Reenacting a female slave or servant gives insight into the hardships endured by the matriarchs of American slaves and, therefore, begins the long journey to address the limitations presented at other Civil War reenactments. Azie Dungey, an actress and historian, began her experience with reenacting through living history as a slave at eighteenth-century Mount Vernon, she hoped to "illuminate important aspects of the experience of enslavement: the severity of the restrictions and burdens it imposed, especially on women, and the self-awareness, fortitude, resilience, and spirited resistance of enslaved people." ${ }^{233}$ As a living historian at a national site, Dungey often found herself in awkward scenarios with ignorant tourists asking inappropriate or misguided questions, such as, “'Why don't you just change your situation?",234 Eventually growing tired of ignorance about African American bondage, she "moved to re-create them in Ask a Slave, which debuted in September 2013."235 Through comedy and satire, Dungey highlights the difficulties of reenacting for modern audiences that "“don't take the time to understand... what's considered a lesser valuable history, which is African American history." ${ }^{236}$ Even with the use of comedy, Dungey acknowledges it is difficult to prepare all reenactors for the difficult task of acquiring all the knowledge needed to give "fully informed answers to the wide range of questions that visitors, some of them historians (or at least buffs) themselves, may ask."237 Also, she stresses the responsibility of portraying "marginalized figures," because, "the politics of race, class, and gender in the present intrude in complicated ways that may obscure rather than illuminate the

\footnotetext{
${ }^{233}$ Ibid., 36 .

${ }^{234}$ Ibid., 38 .

${ }^{235}$ Ibid., 35 .

${ }^{236}$ Ibid., 36 .

${ }^{237}$ Ibid., 37.
} 
past in the encounter. ${ }^{238}$ Nonetheless, Dungey acknowledges that reenacting can serve to promote diverse histories and offers "an opportunity to encourage students to connect oppression in the past with social injustices today."239

The historian Vanessa Agnew suggests that modern history has seen change in conception, with a focus on “"personal experience, social relations and everyday life.",240 Assuming Agnew's conclusions are true, reenacting marginalized roles like slaves and servants meets the needs of an American public that is growing more concerned with everyday, personal concerns - such as social and racial anxieties. Reenacted marginalized roles might prove the best way to reach many white Americans and readdress the shortcomings of the white male anxieties that inspire many at modern Civil War reenactments. Americans are focused on the present and living historians help make those shortcomings real, and therefore, relevant for modern audiences.

As long as there are individuals who, subconsciously or consciously, fight to maintain their social and racial superiority in America, there will be a place for modern Civil War reenactments. For reenactors like Cheri Gainor, her "quest...for the knowledge, understanding and the truth," surrounds "scrubbing cloths," at modern reenactments as a camp laundress. ${ }^{241}$ Although a testament to the hard work of early white women, her role - subconsciously - only reinforces a white masculinity that excludes racial issues and, instead, highlights the military details and white experiences of the War. Moreover, modern social and racial anxieties reinforce the shortcomings of modern reenactments by giving reenactors an opportunity to sustain this nineteenth-century white masculinity.

\footnotetext{
${ }^{238}$ Ibid.

${ }^{239}$ Ibid., 38 .

240 Ibid., 37.

${ }^{241}$ Interview with Union Laundress, Cheri Gainor.
} 
As depicted in Figure 4.2, many reenactors remain determined to educate young students about the importance of Southern attitudes that, historically, associate with racial biases that are purposed to "offend you" in modern America. ${ }^{242}$ Twenty-first century reenactments sustain a white masculine narrative. That nineteenth-century white masculine narrative and accompanying imagery, like the battle flag, are still used and reflect modern racial tensions. If Americans ease white male anxieties, the warrior spirit celebrated at reenactments will be unnecessary.
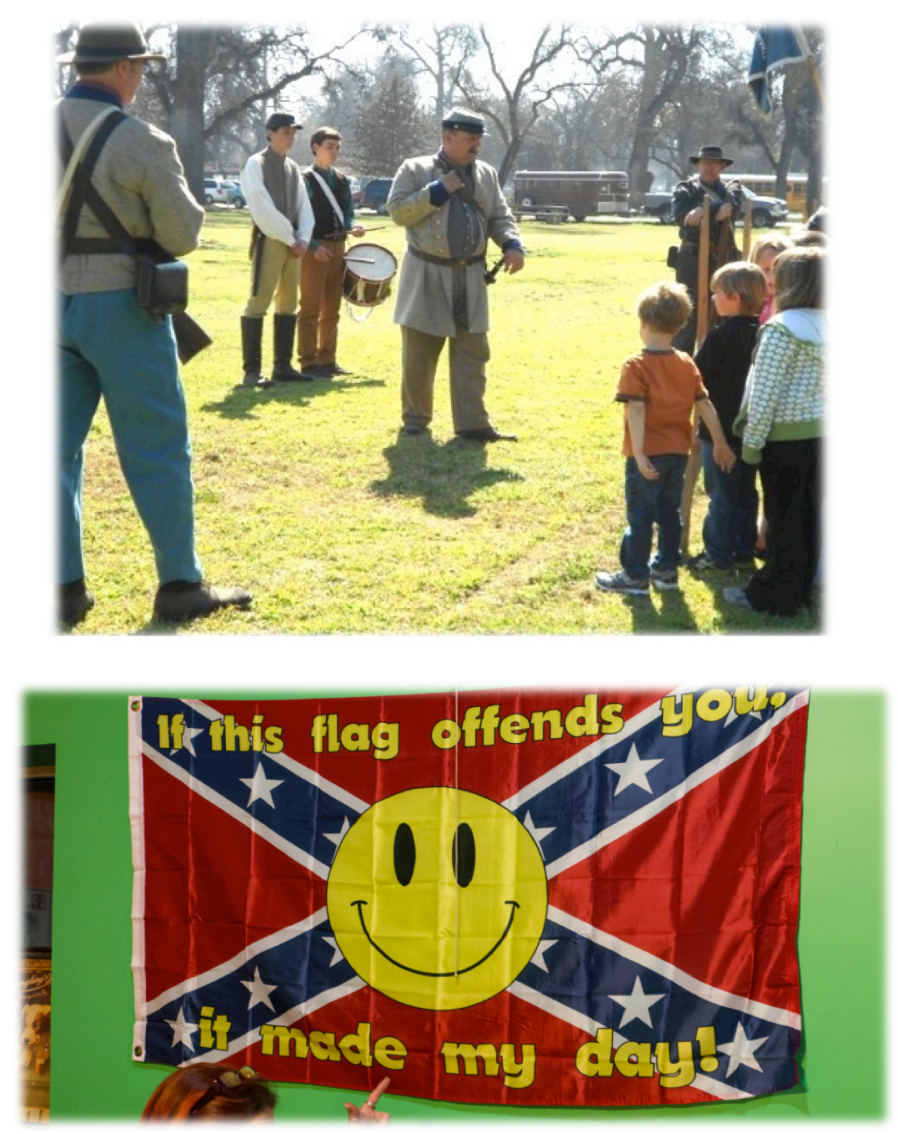

Figure 4.2: In the first photo, a Confederate reenactor instructs young students about the history of the War, as the students stand with wooden rifle replicas.

The second photo depicts the Confederate battle flag with, "If this flag offends you, it made my day!" Second photo by John Ramspott, https://www.flickr.com/photos/jramspott. ${ }^{243}$

\footnotetext{
${ }^{242}$ Ramspott, photographs of the American South, April 23, 2016.

${ }^{243}$ Civil War Reenactment Society depicts the Confederate reenactors on the website gallery, and, Ramspott photographs of the American South, April 23, 2016.
} 
Parents continue to pass down flawed legacies of the War and young reenactors like George Horning Jr. represent a new generation of white American men who love reenacting as camping (Figure 4.3). ${ }^{244}$ In the context of a modern America, consciously or subconsciously, many students do not grasp the "failure of more conventional institutions to educate the public about it (the Civil War and race)." ${ }^{245}$ Despite these shortcomings in American perceptions of the War, the growing role of living historians, like Azie Dungey, provide hope for accurate conceptions of Civil War history, race, and how Americans address the anxieties of the past and the present.
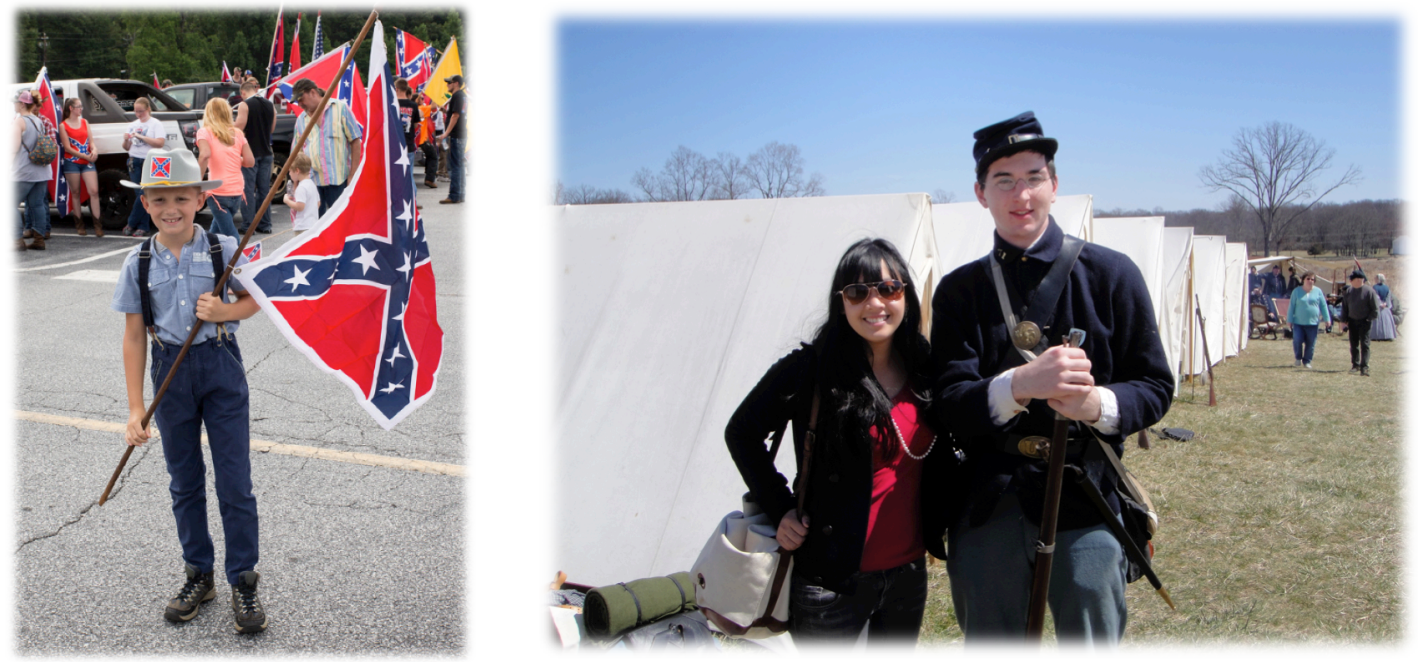

Figure 4.3: In the first photograph, a child poses with the Confederate battle flag and his Southern themed attire at a battle flag rally. The second photograph depicts George Horning Jr., a young man who reenacts a Union soldier. As a hobbyist, Horning reenacts for the camping and because he enjoy military history relevant to his native region (First Photo: by John Ramspott on August 1, 2015, https://www.flickr.com/photos/jramspott. Second Photo: by Austin English on April 6, 2013). ${ }^{246}$

A twenty-first century American public possesses the power to present history as a diverse narrative that incorporates a broad spectrum of experiences and critically reflects upon

\footnotetext{
${ }^{244}$ George Horning Jr., Union Reenactor described reenactments enjoyable for recreation and for those who enjoy learning about history.

${ }^{245}$ Melish. "[Re]Living Slavery" 37. Added "the Civil War and race" for clarification.

${ }^{246}$ Ramspott, photographs of the American South, August 1, 2015, and, George Horning Jr. (Photo by Austin English).
} 
the ways in which modern memory is obtained and sustained for future generations. A willingness to ask thought provoking questions that challenge popular views of American history can, in fact, broaden understandings of the American Civil War and the racial issues and anxieties that arose out of emancipation. However, historian Joanne Melish offers this conclusion with caution. She warns that these debates do not take place "in some neutral space of historical inquiry, but in vexed present-day cultural and political arena. That vexed area extends not to the classroom, where historical role-playing is supported." ${ }^{, 247}$ Dungey, for example, concedes that failing to properly communicate history to future generations comes "from failing to reckon with the present, not the past." ${ }^{\text {248 }}$ Her comments confirm that American history and the issues of the present are not independent entities, but intertwined and everdeveloping in collective history and memory. As recreated television series like Roots premiered on May 30, 2016, the original date assigned to Memorial Day, the series provided a twenty-first century, national audience an opportunity to experience the excruciating horrors of Southern slavery - an unforgettable and unmistakably important narrative to American history. Social efforts through modern media reflect diverse representations of the War and, as a result, highlight roles that modern reenactments rarely accounted for in military portrayals. In the words of Bishop Larry T. Kirkland of Brookins A.M.E. Church in Los Angeles, memory and history require, "an obligation to make things better for the last, the lost, the least, the left-out, and the looked over."249

\footnotetext{
${ }^{247}$ Melish. "[Re]Living Slavery” 38.

${ }^{248}$ Ibid.

${ }^{249}$ Larry T. Kirkland, Bishop at Brookins A.M.E. Church, Los Angeles. "OJ Made in America: Part II” Series, original airdate in June 2016.
} 
As these changes in Civil War memory and reenactments enlighten white Americans, it comes with additional caution not to "cleanse history rather than reckon with it." 250 The goal is to readdress reenactments through accurate representation - not an elimination of the white, masculine narrative, entirely. Gibson identifies in American, masculine culture a need for "myth and ritual even in the heart of the modern secular world." 251 Often recognizing the overemphasized, nineteenth-century white masculinity sustained through Civil War imagery and symbols, some Americans react with contempt, rather than taking the opportunity to reflect. This failure to challenge the critical motives behind their own sanitization of Civil War imagery represents an equal failure in addressing the limitations of the War. Modern media and a general effort on the part of educators, reenactors, living historians, and curious Americans to identify the white masculine narratives of Civil War memory require critical thought and timely consideration. Instead of eliminating and "removing monuments," 252 with no consideration, it is necessary to engage the public and consider the meaning of historical symbols. Controversies like San Diegans opposing the name change of Robert E. Lee Elementary require further discussion as to whether or not personal matters outweigh the racial offenses displayed to a modern American public. A Civil War history, marked by 150 years of pervasively deficient memories and seeded in white masculinity, motivates American opinions on the War and racial issues. These anxieties and racial shortcomings were a product of contempt and a conscious effort to omit racial narratives from national identity and history. Nonetheless, Americans - all Americans - deserve an inclusive, useable history that addresses our nation's shortcomings, recognizes where we have gone, and contemplates what the future holds.

\footnotetext{
${ }^{250}$ Salvador Rivera, "School Board Renames Robert E. Lee Elementary" (Fox News: Fox5sandiego, May 24, 2016).

${ }^{251}$ Gibson, Warrior Dreams, 306.

${ }^{252}$ Rivera, "School Board Renames," (2016).
} 
Nietzsche, "once prophesied war would end when the men of a nation felt so powerful and so positive about themselves...they declared, 'I break the sword." ${ }^{253}$ Can American white men recognize and end misperceptions of history or will persisting anxieties continue a legacy of limited historical representation at modern reenactments? The display of white masculinity at reenactments and the racial anxiety that accompanies it requires resolution through significant societal and cultural change. Unfortunately, Nietzsche's insight proves difficult when American white men, consumed by anxieties, often uphold masculinity through "warrior myths," at modern Civil War reenactments. ${ }^{254}$ Although a difficult task to undertake, Americans may not be able to "break" their "swords" of racism and anxiety overnight - but over time and with conscious effort to explore American history - that sword may dull, blunted and pacified by the same, omitted memories that sustained white social dominance for over a hundred years after the War's end.

${ }^{253}$ Gibson, Warrior Dreams, 308.

${ }^{254}$ Ibid. 


\section{BIBLIOGRAPHY}

\section{BOOKS}

Ayers, Edward. America's War: Talking About the Civil War and Emancipation on their $150^{\text {th }}$ Anniversaries. Library of Congress: American Library Association, 2012.

Barney, William, The Making of a Confederate, Walter Lenoir's Civil War. Oxford University Press, 2008.

Bederman, Gail. Manliness and Civilization: A Cultural History of Gender and Race in the United States, 1880-1917. Chicago and London: The University of Chicago Press, 1995.

Blight, David. American Oracle. Cambridge and London: Belknap Press of Harvard, 2011, and Race and Reunion, The Civil War in American Memory. Cambridge and London: Harvard University Press, 2001.

Brown, Thomas. The Public Art of Civil War Commemoration. Boston and New York: Bedford/St. Martin's, 2004.

Faust, Drew. This Republic of Suffering, Death and the American Civil War. New York: Vintage Civil War Library, 2008.

Gibson, James. Warrior Dreams, Violence and Manhood in Post-Vietnam America. Canada: First Hill and Wang, 1994.

Horwitz, Tony. Confederates in the Attic Dispatches from the Unfinished Civil War. New York: A Division of Random House, Inc., 1999.

Jones, Terry. The American Civil War. University of Louisiana: McGraw-Hill Companies, 2010.

MacLean, Nancy. Behind the Mask of Chivalry, the Making of the Second Ku Klux Klan. New York: Oxford University Press, 1994.

McPherson, James. For Cause and Comrades: Why Men Fought in the Civil War. Oxford University Press: New York and London, 1997.

McPherson, James. What They Fought For, 1861-1865. Louisiana State University Press: First Anchor Books, 1995.

Reardon, Carol. Pickett's Charge in History and Memory. Chapel Hill and London: The University of North Carolina Press, 1997.

Rotundo, E. Anthony. American Manhood: Transformation in Masculinity from the Revolution to the Modern Era. New York: Basic Books, Inc., 1993. 


\section{JOURNALS}

Auslander, Mark. "Touch the Past: Materializing Time in Traumatic 'Living History' Reenactments." Signs and Society, Vol. 1, No.1 (2013).

Banks, Richard, Eberhardt, Jennifer, and Ross, Lee. "Discrimination and Implicit Bias in a Racially Unequal Society." California Law Review, Vol. 94, No. 4 (July 2006).

URL: http://0-www.jstor.org.sally.sandiego.edu/stable/20439061

Bruce, Marino. "Race and Gender Relations in Rituals of Blood." Contemporary Sociology, Vol. 29 (2000). Review of Orlando Patterson's Rituals of Blood: Consequences of Slavery in Two American Centuries

URL: http://0-www.jstor.org.sally.sandiego.edu/stable/2654391

Kornacki, Steve. "The 'Southern Strategy,' Fulfilled.” Salon.com (February 3, 2011).

URL: http://www.salon.com/2011/02/03/reagan_southern_strategy/

Khazan, Olga. "Why Are So Many Middle-Aged White Americans Dying?" The Atlantic (January 29, 2016).

URL: http://www.theatlantic.com/health/archive/2016/01/middle-aged-white-americansleft-behind-and-dying-early/433863/

Mailer, Norman. “The White Man Unburdened.” The New York Review of Books (July 17, 2003). URL: http://www.nybooks.com/articles/2003/07/17/the-white-man-unburdened/

Melish, Joanne. "[Re]Living Slavery: Ask a Slave and the Pitfalls of Portraying Slavery for the Public." The American Historian, No.1, Organization of American Historians (August 2014).

Packer, George. "Southern Discomfort," The New Yorker (January 21, 2013).

URL: http://www.newyorker.com/magazine/2013/01/21/southern-discomfort-4

Patterson, Orlando. "Rituals of Blood: Sacrificial Murders in the Postbellum South," The Journal of Blacks in Higher Education: No. 23 (1999).

URL: http://0-www.jstor.org.sally.sandiego.edu/stable/2999334

Testi, Arnaldo. "Review by: Arnaldo Testi" of Gail Bederman's Manliness and Civilization. Journal of American History, Vol. 82, No. 4 (1996).

URL: http://0-www.jstor.org.sally.sandiego.edu/stable/2945371

Time Life Magazine. "The Civil War on the Front Lines, From Fort Sumter to Appomattox." New York: Time Inc. Books (2016). 
Turner, Rory. "Bloodless Battle: The Civil War Reenacted." TDR: MIT Press, Vol. 34, No. 4 (1990).

Ward, Jason Morgan. "The Cause Was Never Lost." The American Historian, No.6, Organization of American Historians (November 2015).

Wills, Garry. "Dumb America," The New York Review of Books, NYR Daily (January 21, 2013). URL: http://www.nybooks.com/daily/2013/01/21/dumb-america/

\section{MISCELLANEOUS}

Bates, Christopher. "What They Fight For: The Men and Women of the Civil War

Reenactment." PhD diss., University of California Los Angeles, 2016.

URL: https://escholarship.org/uc/item/73w01958.

Davis, Patricia. Lecture notes taken at Dr. Patricia G. Davis' presentation, "More than History and Dates: Black Civil War Re-Enactors Re-Enact Freedom. San Diego Central Library, Joan A Irwin Jacobs Common, March 2, 2015.

URL: sandiego.communityguides.com/civilwar150

Email: Pdavis20@gsu.edu

English, Austin. Visited Civil War Battlefields in Pennsylvania, Virginia, and Maryland;

April, 2013.

Email: Aenglish@sandiego.edu

Kirkland, Larry. Bishop of Brookins A.M.E. Church, Los Angeles. "OJ Made in America: Part II" Series, ESPN Original Air Date: June, 2016.

Miller, David. Class Notes from Civil War and Reconstruction/Civil War and Popular Culture courses at the University of San Diego, California. February 10 and 18, 2015. Email: davidmiller@sandiego.edu

X, Malcolm. "The Ballot or the Bullet," Speech delivered April 12, 1965 in Detroit, USA.

URL: https://www.cis.aueb.gr/Besides\%20Security/TALKS/TALKS-10-

X\%20(The\%20Ballot\%20or\%20the\%20Bullet).pdf

\section{NEWS SOURCES}

Douban, Gigi. Fewer People Participate in Civil War Reenactments. NPR Radio: Conversation between Gigi Douban and Mr. John Nettles, July 4, 2011.

URL: http://www.npr.org/2011/07/04/137609367/fewer-people-participate-in-civil-warreenactments 
Cooper, Matthew. 'Ken Burns's Merciful Portrayal of the South in 'The Civil War' is a Good Lesson for 2015." Newsweek.com, September 11, 2015.

URL: http://www.newsweek.com/pbs-film-celebrates-its-25th-anniversary-ken-burnscivil-war-371366

Lee, Michelle Ye Hee. "Fact Checker: Giuliani's claim that 93 percent of black murder victims are killed by other blacks." TheWashingtonPost.com, The Washington Post.

November 25, 2014.

URL: https://www.washingtonpost.com/news/fact-checker/wp/2014/11/25/giulianisclaim-that-93-percent-of-blacks-are-killed-by-other-blacks/

Rivera, Salvador. "School Board Renames Robert E. Lee Elementary.” Fox5sandiego.com, Fox News. May 24, 2016.

URL: http://fox5sandiego.com/2016/05/24/robert-e-lee-school-name-no-more/

Thompson, Catherine. "Cliven Bundy Wonders if Blacks are 'Better Off as Slaves' than on Gov’t Assistance.” TPM Media: TalkingPointsMemo, April 24, 2014.

URL: http://talkingpointsmemo.com/livewire/bundy-explains-slavery-remarks

\section{PERSONAL INTERVIEWS}

Doolittle, Emma. Civil War Reenactment volunteer in Duncan Mills from 2006-2009. Comments submitted January 29,2015.

URL: http://www.civilwardays.net/home.html. Email: edoolittle@sandiego.edu

Gainor, Cheri. Interview with Union Laundress from Gettysburg Battlefield, Pennsylvania on July 30, 2013. Email: cherimgainor@yahoo.com

Horning, George Jr. Oral Interview with Union reenactor, George Horning Jr. at Gettysburg, Pennsylvania on April 6, 2013. Works at Men's Wearhouse: 2500 Chemical Rd., Plymouth Meeting, PA 19462, Phone: 16105675818

Petzolt, John. Interview with "Living Historian” from Gettysburg Little Round Top, Pennsylvania on July 25, 2013.Sgt1863@comcast.net

\section{PHOTOGRAPHS (if not cited in other section):}

Battle of Vista Reenactment. Vista, San Diego, California. Taken by Austin English on October 26, 2011.

Battle of Vista Reenactment. Vista, San Diego, California. Taken by Austin English on March 17, 2011. 
Battle of Vista Reenactment. Vista, San Diego, California. Taken by Austin English on April 23, 2015.

Ramspott, John. Photographer for Figure 3.4. Reference John Ward's "The Cause Was Never Lost" from The American Historian, November 2015, 24.

URL(s): https://www.flickr.com/photos/jramspott/20209219132/

https://www.flickr.com/photos/jramspott/20209155552/in/album-72157656667412591/

https://www.flickr.com/photos/jramspott/26036669663/

https://www.flickr.com/photos/jramspott/26367041470/

https://www.flickr.com/photos/jramspott/26366752440/

https://www.flickr.com/photos/jramspott/26613636416/

\section{WEB SITES}

American Civil War Association, About (Drupal, 2012).

URL: http://www.acwa.org/about.

American Civil War Society, Inc. About ACWS (2001-2004).

URL: http://www.acws.net/about_acws.htm

Civilwaralliance.com. Displays information for Southern California reenactments that have no historical or geographical relevance to the Civil War, 2012.

URL: http://civilwaralliance.com/CWA/Vista.html

Civil War Reenactment HQ. "How to Get Started in Civil War Reenacting," Civil War Reenactment Headquarters for Civil War Reenacting Events, Units, and Information, 2001.

URL: http://www.reenactmenthq.com/beginners.php

Civil War Reenactment Society. "Welcome" Page, January 25, 2015.

URL: http://www.cwrs.info/Civil_War_Reenactment_Society/Home.html

Civilwartraveler.com. Displays a number of references to participate in or view "Living History" or "Reenactments," 2014.

Dreifus, Claudia. Perceptions of Race at a Glance, A MacArthur Grant Winner Tries to Unearth Biases to Aid Criminal Justice. NewYorkTimes.com, January 5, 2015.

URL: http://www.nytimes.com/2015/01/06/science/a-macarthur-grant-winner-tries-tounearth-biases-to-aid-criminal-justice.html?_r $=0$ 
Eberhardt, Jennifer, "How Racial Residue: how Race Alters Perception of People, Places, and Things." Lecture at Cornell University, College of Human Ecology, Human Development Outreach and Extension, February 18, 2011. URL: http://www.cornell.edu/video/how-race-alters-perception-of-people-places-andthings

Gettysburg Anniversary Committee. About GAC. Gettysburg Anniversary Civil War Reenactment, 2014.

URL: http://www.gettysburgreenactment.com/about-gac/

Gold Coast Festivals. Vista Civil War Reenactment, 2014.

URL: http://www.goldcoastfestivals.com/vistacivilwarhome.html

Jorgensen, Kathryn. Gettysburg $150^{\text {th }}$ Brings Thousands to Programs, Battlefield, Reenactments. Historical Publishing Inc.: CiviCivilWarNews.com, 2013.

URL: http://www.civilwarnews.com/archive/articles/2013/aug/gbrg-081301.htm

National Park Service, “1963 Commemoration of Pickett's Charge” National Park Service Centennial, U.S. Department of the Interior, July 3, 1963.

URL: http://www.nps.gov/media/photo/gallery.htm?id=C78A0AA0-155D-451F6792278A97619590

Nevada Civil War Volunteers, "About the Nevada Civil War Volunteers" Bulletins From the Front, January 19, 2016.

URL: www.nevadacivilwar.org 